\title{
13 An Analysis of the Evolution
of Insurance in India
}

Tapen Sinha

Instituto Tecnologico Autonomo de Mexico and University of Nottingham

\subsection{Introduction}

India had the nineteenth largest insurance market in the world in 2003. Strong economic growth in the last decade combined with a population of over one billion makes it one of the potentially largest markets in the future. Insurance in India has gone through two radical transformations. Before 1956, insurance was private with minimal government intervention. In 1956, life insurance was nationalized and a monopoly was created. In 1972, general insurance was nationalized as well. ${ }^{256}$ But, unlike life insurance, a different structure was created for the industry. One holding company was formed with four subsidiaries. As a part of the general opening up of the economy after 1992, a government-appointed committee recommended that private companies should be allowed to operate. It took six years to implement the recommendation. The private sector was allowed into the insurance business in 2000. However, foreign ownership was restricted. No more than 26 percent of any company can be foreign-owned.

This chapter examines the insurance industry in India through different regulatory regimes. A totally regulation-free regime ended in 1912 with the introduction of regulated life insurance. A comprehensive regulatory scheme came into place in 1938. This was disabled through nationalization, but the Insurance Act of 1938 became relevant again in 2000 with deregulation. With a strong hint of sustained growth of the economy in the recent past, the Indian market is likely to grow substantially over the next few decades.

The rest of the chapter is organized as follows. First, we study the evolution of the Indian insurance business before nationalization. This is important because the denationalized structure brought back to play important legal rules from 1938. Second, we analyze the nationalized era separately for life and property-casualty business, because they were not nationalized simultaneously. Much of the post-

\footnotetext{
${ }^{256}$ The term general insurance is used in Britain and other Commonwealth countries. Elsewhere, the equivalent term is property-casualty insurance or non-life insurance.
} 
independence history of insurance in India was the history of nationalized insurance. Third, we examine the new legal structure introduced after the industry was denationalized in 2000. Finally, we examine the current state of play and the projected future of the industry.

\subsection{Evolution of Insurance Before Nationalization}

\subsubsection{Insurance in the Colonial Era}

Life insurance in the modern form was first set up in India through a British company called the Oriental Life Insurance Company in 1818, followed by the Bombay Assurance Company in 1823 and the Madras Equitable Life Insurance Society in 1829. All of these companies operated in India but did not insure the lives of Indians. They insured the lives of Europeans living in India. ${ }^{257}$

Some of the companies that started later did provide insurance for Indians, but they were treated as "substandard." Substandard in insurance parlance refers to life insurance for people with physical disability. In this case, the common adjustment made was a "rating-up" of five to seven years to the normal life expectancy of a British person in India. This meant, treating $\mathrm{q}(\mathrm{x})$, the (conditional) probability of dying between $x$ and $x+1$, for an $x$-year-old Indian male as if it was $q(x+5)$ or $q(x$ $+7)$ of a British male. Therefore, Indians had to pay an ad hoc extra premium of 20 percent or more. This was a common practice of European companies that were operating in Asia or Latin America. The first company to sell policies to Indians with "fair value" was the Bombay Mutual Life Assurance Society starting in 1871.

The first general insurance company, Triton Insurance Company Ltd., was established in 1850. It was owned and operated by the British. The first indigenous general insurance company was the Indian Mercantile Insurance Company Limited, established in Bombay in 1907.

At the time, insurance business was conducted in India without any specific regulation Insurers were subject to the Indian Companies Act of 1866, but the insurance industry was otherwise unregulated. After the start of the "Be Indian Buy Indian" movement (called the Swadeshi movement) in 1905, indigenous enterprises sprang up in many industries. Not surprisingly, the movement also touched the insurance industry, leading to the formation of dozens of life insurers along with provident fund companies (pension funds). In 1912, two sets of legislation were passed: the Indian Life Assurance Companies Act and the Provident Insurance Societies Act. There are several striking features of these legislations. First, they were the first legislations in India that particularly targeted the insurance sector. Second, they did not apply to general insurance, because the government did not feel the necessity to regulate general insurance. Third, they restricted activities of Indian insurers but not foreign insurers, even though the legislation was modeled after the British Act of 1909.

\footnotetext{
${ }^{257}$ An excellent history of Indian business can be found in Tripathi (2004). It gives a detailed account of the rise of business houses in India during the colonial period.
} 
Comprehensive insurance legislation covering both life and non-life business did not materialize for the next 26 years. During the first phase of these years, Great Britain entered World War I - an event that disrupted all legislative initiatives. Later, Indians demanded freedom from the British. As a concession, India was granted "home rule" through the Government of India Act of 1935, which provided for legislative assemblies for provincial governments as well as for the central government. But supreme authority of promulgated laws remained with the British Crown.

The only significant legislative change before the Insurance Act of 1938 was Act XX of 1928. It enabled the government of India to collect information about (1) Indian insurers operating in India, (2) foreign insurers operating in India, and (3) Indian insurers operating in foreign countries. The last two elements were missing from the 1912 Insurance Act. Information thus collected allows us to compare the average face value of Indian insurers to their foreign counterparts. In 1928, the average policy value of an Indian company was U.S. $\$ 619$ compared to $\$ 1,150$ for foreign companies (Indian Insurance Commissioner's Report, 1929, p. 23).

Foreign insurers were doing well during that period. In 1938, the average size of the policy sold by Indian companies had fallen to U.S. \$532 (compared to \$619 in 1928 ), and that of foreign companies had risen somewhat to $\$ 1,188$ (in 1928 , the average size was $\$ 1,150)$.

\subsubsection{The Insurance Act of 1938}

In 1937, the government of India set up a consultative committee. Sushil C. Sen, a well-known solicitor in Calcutta, was appointed the chair of the committee. He consulted a wide range of interested parties, including leaders within the insurance industry. It was debated in the legislative assembly, and, finally, in 1938, the Insurance Act was passed. This was the first comprehensive piece of legislation in India, covering both life and general insurers. It clearly defined the various lines of business in the insurance industry (see Appendix 1). It covered deposits, supervision of insurers, investments, commissions of agents, and directors appointed by the policyholders, among other topics. This piece of legislation lost significance after life insurance was nationalized in 1956, and general insurance was nationalized in 1972. With the privatization in the late twentieth century, the Insurance Act of 1938 returned as the backbone of current legislation of insurers. All legislative changes are enumerated in Table 13.1.

To implement the 1938 Act, an insurance department was established in the Ministry of Commerce by the government of India; later it was transferred to the Ministry of Finance. One curious element of the Act's classification of lines of insurance business was its inclusion of automobile insurance in the "miscellaneous" category. Later in the century, automobiles became the largest single item of general insurance. However, it continued to be included in the miscellaneous category, making it difficult to delineate the effects of losses due to pricing that drove this sector. For example, the Tariff Advisory Committee effectively fixed prices for a number of general insurance lines of business. Most premiums were below what would have been actuarially fair (especially for auto), but reporting auto insurance under the miscellaneous category masked this underpricing. 
When the market was opened again to private participation in 1999, the earlier Insurance Act of 1938 was reinstated as the backbone of the current legislation of insurers, as the Insurance Regulatory and Development Authority Act of 1999 was superimposed on the 1938 Insurance Act. This revival of the earlier legislation has created a messy problem in that the Insurance Act of 1938 explicitly forbade insurers to participate in other financial services activities such as banking.

Table 13.1. Milestones of Insurance Regulations in India

\begin{tabular}{|c|c|}
\hline Year & Significant Regulatory Event \\
\hline 1912 & The Indian Life Insurance Company Act \\
\hline 1928 & Indian Insurance Companies Act \\
\hline 1938 & The Insurance Act: Comprehensive Act to regulate insurance business in India \\
\hline 1956 & $\begin{array}{l}\text { Nationalization of life insurance business in India with a monopoly awarded to the } \\
\text { Life Insurance Corporation of India }\end{array}$ \\
\hline 1972 & $\begin{array}{l}\text { Nationalization of general insurance business in India with the formation of a } \\
\text { holding company, General Insurance Corporation }\end{array}$ \\
\hline 1993 & Malhotra Committee established \\
\hline 1994 & Recommendations of Malhotra Committee published \\
\hline 1995 & Mukherjee Committee established \\
\hline 1996 & $\begin{array}{l}\text { Setting up of (interim) Insurance Regulatory Authority (IRA) Recommendations of } \\
\text { the IRA }\end{array}$ \\
\hline 1997 & Mukherjee Committee Report submitted but not made public \\
\hline 1997 & $\begin{array}{l}\text { The government gives greater autonomy to Life Insurance Corporation, General } \\
\text { Insurance Corporation, and its subsidiaries with regard to the restructuring of } \\
\text { boards and flexibility in investment norms aimed at channeling funds to the } \\
\text { infrastructure sector }\end{array}$ \\
\hline 1998 & $\begin{array}{l}\text { The cabinet decides to allow } 40 \text { percent foreign equity in private insurance } \\
\text { companies- } 26 \text { percent to foreign companies and } 14 \text { percent to nonresident Indians } \\
\text { and Foreign Institutional Investors }\end{array}$ \\
\hline 1999 & $\begin{array}{l}\text { The Standing Committee headed by Murali Deora decides that foreign equity in } \\
\text { private insurance should be limited to } 26 \text { percent. The IRA bill is renamed the } \\
\text { Insurance Regulatory and Development Authority Bill }\end{array}$ \\
\hline 1999 & Cabinet clears Insurance Regulatory and Development Authority Bill \\
\hline 2000 & President gives assent to the Insurance Regulatory and Development Authority Bill \\
\hline
\end{tabular}

By 1956, there were 154 Indian life insurers. There were 16 non-Indian insurers, and 75 provident societies were issuing life insurance policies. Most of these policies were centered in the big cities of Bombay, Calcutta, Delhi, and Madras.

\subsubsection{Mortality Tables}

Before the mortality of Indian lives were used for constructing mortality tables for India, it was common practice to use the British Office Table based on the British 
experience during 1863 to 1893 . As noted earlier, the table was used with a rating up of five to seven years to approximate Indian lives. The first ever Indian table based on assured Indian lives was created based on the experience of the Oriental Government Security Life Assurance Co. Ltd. for the period 1905 to 1925 (Vaidyanathan, 1934). It was noted that the lowest mortality was experienced by the endowment policies, and the highest mortality was experienced by the whole life policies. Subsequent updates were produced by the Life Insurance Corporation in the 1970s (LIC 75-79) and in the 1990s (LIC 94-96).

Given that the Life Insurance Corporation was a monopoly, it had no incentive to update mortality tables frequently. Indeed, the Malhotra Committee (1994) noted this fact: "Quite a few persons including, notably, representatives of consumer groups have told the Committee that Life Insurance Corporation premium rates had remained unrevised for a long period and were unjustifiably high in spite of the fact that trends in mortality rates all over the country are continuously showing improvement" (chap. 5, sect. 5.4, p. 33). The Report recommended that such tables be published every ten years (chap. 5, section 5.12, p. 37).

\subsection{EVOLUTION OF INSURANCE DURING THE NATIONALIZED ERA: 1956 TO 2000}

\subsubsection{Rationale for Nationalization}

After India became independent in 1947, a National Planning initiative modeled after the Soviet Union's was implemented. Prime Minister Jawaharlal Nehru's vision was to have key industries under direct government control to facilitate the implementation of National Planning. Insurance business (or, for that matter, any financial service) was not seen to be of strategic importance.

Such a planning strategy begs two questions: First, why did the government of India nationalize life insurance in 1956? Second, why did it not nationalize general insurance at the same time?

We deal with the first question first. The genesis of nationalization of life insurance came from a document produced by H. D. Malaviya called "Insurance Business in India" on behalf of the Indian National Congress. Malaviya had written a dozen books, and this was one of the more obscure ones. ${ }^{258}$ In that document, he made four important claims to justify nationalization. First, he argued that insurance is a "cooperative enterprise" under a socialist form of government, and, therefore, it is more suited for government to be in the insurance business on behalf of the people. Second, he claimed that Indian companies are excessively expensive. Third, he argued that private competition has not improved services to the public or to the policyholders. Preventative activities such as better public health, medical check-ups, and hazard prevention activities did not improve under privatization. Fourth, lapse ratios of life policies were very high, leading to "national waste."

\footnotetext{
${ }^{258}$ I am indebted to Professor Alan Heston of the University of Pennsylvania for drawing my attention to this document.
} 
Malaviya's argument for the high cost of Indian insurance is the only one that he backed up with data (his other claims were made in vague terms), so we can take a closer look at his evidence on this point. Based on some data, he presents what he called "overall expenses" of insurance business operation in India, the United States, and the United Kingdom. His calculations are shown in Table 13.2. He found that it costs Indian insurers 27 to 28 percent of premium income for insuring lives, whereas in the United States, the corresponding figure is 16 to 17 percent. In the United Kingdom, it is even lower at 13 to 14 percent. On the face of it, this argument seems watertight. Unfortunately, this is not the case. On closer inspection of how the numbers were arrived at, we find that for the calculation, the denominator used for India is not the same as that used for the United States and the United Kingdom. For the Indian data, the denominator uses premium income only, whereas, for the other two countries, the denominator uses total income that includes premium income and investment income (as is customary the world over).

Table 13.2. Percentages of Premium Income Used to Insure Lives (or Overall Expenses of Life Insurance Business) in India, the United States, and the United Kingdom

\begin{tabular}{|c|c|c|c|}
\hline Year & India & United States & United Kingdom \\
\hline 1950 & 28.9 & 16.8 & 13.0 \\
\hline 1951 & 27.2 & 16.5 & 14.1 \\
\hline 1952 & 27.1 & 16.7 & 14.2 \\
\hline 1953 & 27.3 & 17.0 & 14.5 \\
\hline
\end{tabular}

Source: Malaviya, n.d..

Finance Minister C. D. Deshmukh announced nationalization of the life insurance business. In his speech, he justified the action as follows.

"With the Second Plan, involving an accelerated rate of investment and development, the widening and deepening of all possible channels of public savings has become more than ever necessary. Of this process, the nationalization of insurance is a vital part." He then went on to declare, "The total [life] insurance in force exceeds Rs. 10,000 millions, that is a little over Rs. 25 per head. Quite recently it was claimed on behalf of a private enterprise that business in force could be increased to Rs. 80,000 millions and per capita insurance to Rs. 200. I am in complete agreement. There can be no doubt as to the possibilities of life insurance in India and I mention these figures only to show how greatly we could increase our savings through insurance." He added, "Thus even in insurance which is a type of business which ought never to fail if it is properly run, we find that during the last decade as many as twenty five life insurance companies went into liquidation and another twenty five had so frittered away their resources that their business had to be transferred to other companies at a loss to the policyholders."

Thus, the nationalization was justified based on three distinct arguments. First, the government wanted to use the resources for its own purpose. Apparently, the 
government was not willing to pay the market rate of return for the assets (otherwise, it could have raised the capital whether insurers were private or public). Second, it sought to increase market penetration by nationalization. How could nationalization possibly deepen the market that private insurers could not? There are two possibilities. (1) Nationalization would create a monopoly. If there are economies of scale in the market, it would become possible for the government to cut the cost of operation per policy sold below what private companies could. (2) Through nationalization, the government could take life insurance into rural areas, where it was not profitable for private businesses to sell insurance. Third, the government found the number of failures of insurers to be unacceptable and claimed that the failures were the result of mismanagement.

Given that, by the end of the century, the government did denationalize life insurance, we can examine in some detail whether nationalization did succeed in these three areas. The government did succeed in channeling the resources of life insurance business into infrastructure. The Life Insurance Corporation of India, as of March 2001, had a total sum assured of U.S. \$155 billion. The value of its life fund was $\$ 40$ billion. The book value of Life Insurance Corporation's “socially oriented investments" 259 - mainly comprised of government securities holdings-at March 31,2001 , amounted to $\$ 27$ billion (73 percent of a total portfolio value of $\$ 37$ billion). In total, 84 percent of Life Insurance Corporation's portfolio comprises exposure to the public sector (see Bhattacharya and Patel, 2003, and Appendix 2). The Reserve Bank of India Weekly Statistical Supplement of October 11, 2003, shows that 52 percent of the outstanding stock of government securities is held by just two public sector institutions: the State Bank of India and the Life Insurance Corporation of India, approximately in equal proportions.

Did the nationalization and consequent creation of monopoly actually reduce the cost of issuing life insurance policies? If we take a simple view of the world and calculate overall costs, we arrive at the results shown in Table 13.3. If we calculate overall expenses as a percentage of premium income, we arrive at the following. In 1957, the expenses were 27.7 percent. By 1963, the expenses rose to 29.3 percent. They fell back to 27.9 percent by 1982 and to 21.5 percent in 1992 . In 2002, expenses rose to 22.9 percent. Could we conclude that in the late 1980 s economies of scale kicked in? The answer is negative. The reason is explained in the Malhotra Committee Report (1994, chap. 5, sect. 5.5, p. 34). The expense ratio reported there was 29 percent in 1958 and 25 percent in 1992. The Report excludes group polices from its calculation. Group polices are much cheaper to sell (per policy). These policies did not exist in 1958. But, starting in the 1980 s, they became commonplace. Thus, the naïve calculation along this line will lead us to believe that the expense ratio has come down substantially, whereas, in reality, that is an incorrect conclusion. A number of government reports have come to the same wrong conclusion (for example, the Annual Report of the Ministry of Finance 1995-96, p. 3).

The finance minister addressed the question of why general insurance was not being nationalized in 1956 in his speech as follows.

\footnotetext{
${ }^{259}$ Social sector investments mean loans to state electricity boards, housing, municipalities, water and sewerage boards, state road transport corporations, roadways, and railways. These account for about one fifth of the socially oriented investments portfolio, with the balance accounted for by government and government-guaranteed securities.
} 
"I would also like to explain briefly why we have decided not to bring in general insurance into the public sector. The consideration which influenced us most is the basic fact that general insurance is part and parcel of the private sector of trade and industry and functions on a year to year basis. Errors and omission and commission in the conduct of its business do not directly affect the individual citizen. Life insurance business, by contrast, directly concerns the individual citizen whose savings, so vitally needed for economic development, may be affected by any acts of folly or misfeasance on the part of those in control or be retarded by their lack of imaginative policy."

Table 13.3. Financial Performance of Life Insurance Corporation of India 1957 to 1992 (in millions of U.S. dollars)

\begin{tabular}{|c|c|c|c|c|c|}
\hline & 1957 & 1963 & 1972 & 1982 & 1992 \\
\hline \multicolumn{6}{|l|}{ Income } \\
\hline Total premium income & 139.02 & 253.42 & 516.16 & $1,284.81$ & $2,836.36$ \\
\hline Income from investment & 30.28 & 59.04 & 180.93 & 727.22 & $1,511.72$ \\
\hline Total income & 169.30 & 312.45 & 697.09 & $2,012.03$ & $4,348.08$ \\
\hline \multicolumn{6}{|l|}{ Outgo } \\
\hline Commissions etc. to agents & 12.08 & 23.65 & 48.74 & 108.33 & 274.36 \\
\hline $\begin{array}{l}\text { Salaries and other benefits to } \\
\text { employees }\end{array}$ & 19.14 & 37.40 & 76.95 & 126.27 & 284.02 \\
\hline Other expenses of management & 7.22 & 13.25 & 18.15 & 41.14 & 90.91 \\
\hline Taxes etc. & & & 0.26 & 56.75 & 150.11 \\
\hline $\begin{array}{l}5 \text { percent valuation surplus paid to } \\
\text { government }\end{array}$ & & 2.85 & & & 37.43 \\
\hline \multicolumn{6}{|l|}{ Payments to policyholders } \\
\hline Claims by maturity & 32.64 & 52.49 & 101.99 & 369.94 & 796.73 \\
\hline Claims by death & 12.40 & 21.13 & 34.57 & 91.14 & 180.47 \\
\hline Annuities & 0.78 & 0.67 & 1.99 & 8.23 & 37.00 \\
\hline Surrenders & 6.90 & 8.55 & 25.43 & 82.49 & 257.39 \\
\hline Total outgo & 91.16 & 160.00 & 308.08 & 884.28 & $2,108.42$ \\
\hline Excess of income over outgo & 78.14 & 152.45 & 389.01 & $1,127.74$ & $2,239.67$ \\
\hline Operating cost/premium income & $27.70 \%$ & $29.30 \%$ & $27.90 \%$ & $21.50 \%$ & $22.90 \%$ \\
\hline Operating cost/total income & $22.70 \%$ & $23.80 \%$ & $20.60 \%$ & $13.70 \%$ & $14.90 \%$ \\
\hline
\end{tabular}

Source: Malhotra Committee Report, 1994, Appendix 26, p. 148.

Note: All figures are converted to U.S. dollars using the average exchange rate of that year.

Thus, he did not deem general insurance to be "vitally needed for economic development." The only way this view could be justified is if we view insurance as a vehicle for long-term investment and if we ignore the elimination of uncertainty through insurance as a relatively minor benefit. After all, general insurance reduces 
uncertainty for the non-life category the same way life insurance reduces uncertainty for life.

\subsubsection{Rural Insurance}

In his budget speech, Finance Minister Deshmukh had specific hopes for rural insurance. He announced, "It will be possible to spread the message of insurance as far and as wide as possible, reaching out beyond the most advanced urban areas and into hitherto neglected, namely, rural areas."

After nationalization, Life Insurance Corporation has specifically targeted the rural insurance market. To promote rural insurance, it followed a segmented approach to the market. First, it targeted the rural wealthy with regular individual policies. Second, it offered group policies to people who could not afford individual policies. For the very poor, it offered government-subsidized policies.

In India today more than half of the population live in rural areas and contribute a quarter of the gross domestic product (GDP). Thus, the policymakers felt that it was essential to bring life insurance business to the rural population. Did the policymakers succeed in bringing insurance in the rural sector? Exactly to whom in the rural sector did they manage to bring life insurance?

The "success" of the rural expansion can be measured in a number of different dimensions. Here we are not talking about success necessarily in the sense of commercial success of higher profits. The finance minister was talking about a social objective of bringing insurance cover for the "neglected" rural areas. After all, if profits were to be made in rural insurance, the private sector would not have neglected rural areas. Therefore, we will measure success in terms of the penetration of life insurance into rural areas.

First, we examine the penetration of life insurance in terms of individual policies. The earliest figure we have is for 1961. Around 36 percent of all the individual life policies sold were in the rural sector. This proportion fell to 29 percent by 1970 . Then, from 1980, the proportion started to climb. It climbed steadily for a decade, and, between 1995 and 1999, it climbed even faster with fully 57 percent of all policies sold being in the rural sector. This increase between 1980 and 1999 is remarkable for two reasons. First, the proportion of people living in rural areas has been falling steadily since 1950 . Second, the fall in the proportion had not only halted since 1980 but it had been reversed. Thus, there is no question that the Life Insurance Corporation, through deliberate policy change, managed to penetrate the rural market since 1980 in a way they could not earlier. Of course, the number of individual policies gives us only part of the story.

Another way of examining the rural insurance business is in terms of the value of the insurance policies sold. This is depicted in Figure 13.1. During no period under study did the value of individual life insurance sold in the rural areas as a proportion of the total value of all individual life insurance policies sold in India exceed 40 percent. During the late 1990s, even though the number of rural individual life policies sold kept climbing as a proportion of all individual life policies sold, the value of those policies did not. This implies that there were more policies sold with a smaller average value. This would imply that the profitability of each policy sold in rural areas in the late 1990s fell. 
Finally, we examine the value of the average individual life policy sold in the rural areas as a percent of the average of all the individual life policies sold nationwide. In 1961, this proportion was 84 percent. It fell almost steadily to 74 percent by 1970 and then climbed back to 84 percent in 1990. It has hovered around that figure since. If we compare the per capita income in the rural areas with the per capita income in the urban areas, for almost all states there is a 50 percent difference. Specifically, if the average rural income is 100 , for most states, the average urban income is 150 . Therefore, the individual life insurance policies in the rural areas are not being bought by the average rural households but by the relatively wealthy rural households.

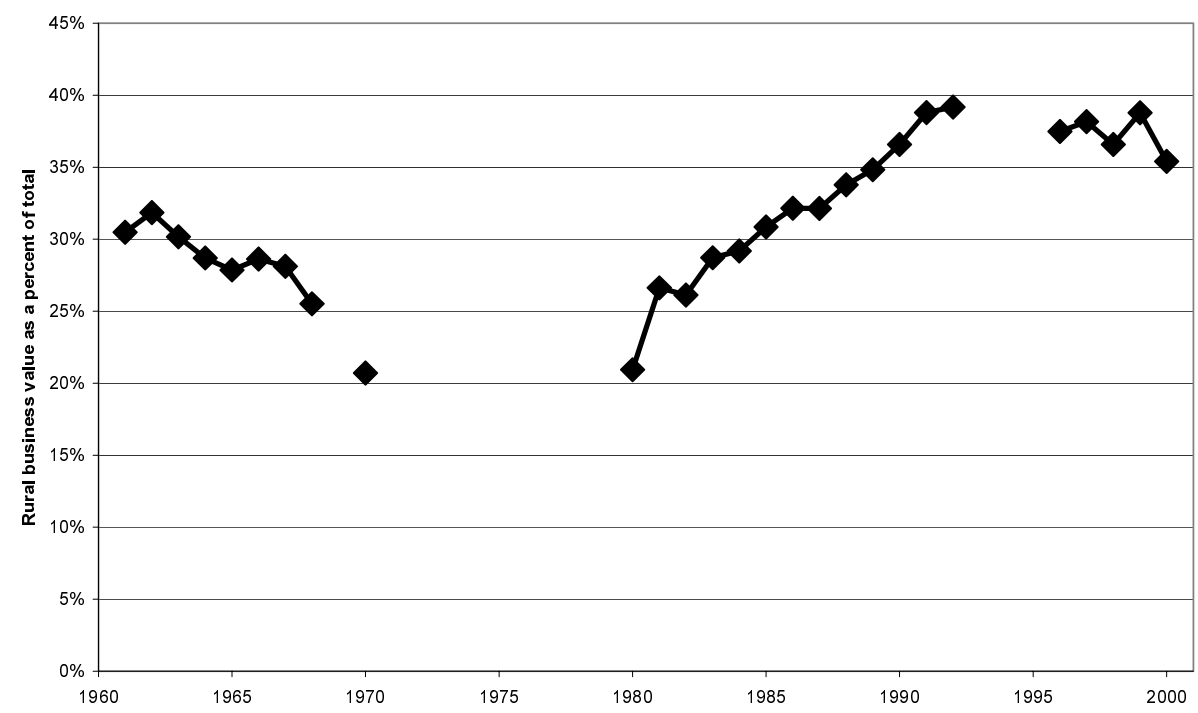

Source: Life Insurance Corporation annual reports, various years.

Figure 13.1. Rural Share of Life Insurance Business by Value, 1960 to 2000

These observations about the value of the policies being sold in rural areas and the issue of who is buying the policies in rural areas raise an uncomfortable question. Has the expansion of the Life Insurance Corporation in the rural areas served the rural rich at the high cost of reduced profitability of the company? Obviously, this was not the intention when the finance minister spoke of serving the neglected rural areas in his speech at the eve of nationalizing life insurance in 1956.

\subsubsection{Prelude to Nationalization of General Insurance: Birth of the Tariff Advisory Committee}

The first collective measures to regulate rates and terms and conditions go back to 1896, with the formation of the Bombay Association of Fire Insurance agents. By 1950, there was a set of rate regulations accepted by most insurers. The Insurance Act of 1938 was amended in 1950 to set up a Tariff Committee under the control of the General Insurance Council of the Insurance Association of India. Main lines of 
general insurance came under the Tariff Committee (they included marine, fire, and miscellaneous, which included auto). Over the next 18 years, the Tariff Committee prevailed as the "rate-maker." It was obligatory for all insurers to comply with its terms and conditions.

In 1968, the Insurance Act of 1938 was amended further. A Tariff Advisory Committee replaced the Tariff Committee. The Tariff Advisory Committee became a statutory body. Section 64UC(2) of the Act stated:

"In fixing, amending or modifying any rates, advantages, terms or conditions relating to any risk, the [Tariff] Advisory Committee shall try to ensure, as far as possible, that there is no unfair discrimination between risks of essentially the same hazard, and also that consideration is given to past and prospective loss experience: provided that the [Tariff] Advisory Committee may, at its discretion, make suitable allowances for the degree of credibility to be assigned to the past experience including allowances for random fluctuations and may also, at its discretion, make suitable allowance for future hazards of conflagration or catastrophe or both."

The introduction of the Tariff Advisory Committee was seen as an independent, impartial, scientifically driven body for ratemaking in general insurance. After the nationalization of general insurance in 1972 (see below), the Tariff Advisory Committee became the servant of the nationalized companies. For example, the chairman of the General Insurance Corporation, the holding company of four nationalized subsidiaries, also became the chairman of the Tariff Advisory Committee. All members of the Tariff Advisory Committee were nominated by the General Insurance Corporation. It came under heavy criticism from the Malhotra Committee. The Report (1994) stated that "the data supplied [by the nationalized companies] was often incomplete and outdated and, over the years, the system has almost broken down" (chap. 5, sect. 5.25, p. 41).

The rates implemented by the Tariff Advisory Committee did not necessarily reflect the market price. For example, after the 1982 and 1988 amendments of the Motor Vehicles Act of 1939, third-party liability became unlimited. It became clear that premium rates had to be revised upward to reflect this change in law. However, political pressure from transporters prevented this rise in premium (Malhotra, 1994, chap. 5, sect. 5.26, p. 41).

Back in 1994, the Malhotra Committee recommended a delinking of the Tariff Advisory Committee from the General Insurance Corporation. It also recommended a gradual phasing out of the Tariff Advisory Committee, with the exception of a few areas. However, it did not set a timetable for this process. A recent report of a special committee set up by the Insurance Regulatory and Development Authority suggests an abolition of the Tariff Advisory Committee by April 1, 2006 (see Report of the Expert Committee, Insurance Regulatory and Development Authority, December 2003).

In India, the Tariff Advisory Committee sets a floor-or minimum-price, and all insurers must charge at least that minimum price. They could charge more (with the approval of the Tariff Advisory Committee). It should be emphasized that tariffication, or setting a floor price, is not unique to India. Neither is the practice followed only in developing countries. The Malhotra Committee Report (1994) noted that Japan and Germany had similar floor prices in place; however, the rates 
were periodically reviewed and adjusted according to the market experience (chap. 5, sect. 5.17, p. 39). In Japan, tariffs were abolished with the liberalization of insurance in 1998. In Malaysia, motor and fire insurance are still subject to tariff regulations. In Indonesia, a tariff regime was introduced in 1983 and continued until 1996. In India, the removal of tariffs was introduced in 1994 in the marine hull business only-the segment of the market dominated by foreign companies. Due to political pressure, it refrained from removing tariffs in the entire cargo insurance segment (Srinivasan, 2003).

Any move away from a tariffed regime is not always popular. What usually follows is rising premiums in some lines. For example, in India, motor insurance prices will rise with the removal of tariffs, and this will probably be pinned as a folly of privatization. Of course, such premium adjustment has nothing to do with privatization per se. Government-owned insurers could take a loss in the motor insurance business (as they did during the 1990s) and cover the deficit from other lines of business. But privately run insurers would seek to generate profit from every line of business. As a result, motor insurance premiums will rise to cover losses. Similarly, rating systems based on drivers' age and experience will be slowly introduced. It will be a long process because the new systems require individual specific past information that can be gathered cost effectively only with computerization of vehicle accident information and other risks.

\subsubsection{Reinsurance}

A reinsurer in India was defined clearly for the first time in the Insurance Act of $1938 .{ }^{260}$ Indian currency has not been convertible since independence. Thus, to retain the maximum possible premium within India and thereby "preserve" foreign currency became a priority for the reinsurance business. India did not have a floating exchange rate until the 1990s. Therefore, hard currencies (like the U.S. dollar) were considered valuable resources. Thus, the policy was to pay minimum possible premiums in hard currencies. To achieve this goal, the insurance companies in India formed the India Reinsurance Corporation in 1956. This was a voluntary agreement at the time. In 1961, the government created the Indian Guarantee and General Insurance Company. By amendment to Section 101A of the Insurance Act, the government required all companies to give statutory cession of 10 percent each to the India Reinsurance Corporation and to the Indian Guarantee and General Insurance Company. This requirement has been echoed in the Act passed in $2000 .^{5}$ The only reinsurance company allowed to operate in India is the General Insurance Corporation.

\footnotetext{
${ }^{260}$ Section 101A(8)(ii), Insurance Act of 1938 states: “'Indian re-insurer' means an insurer specified in sub-clause (b) of clause (9) of section 2 (any body corporate carrying on the business of insurance, which is a body corporate incorporated under any law for the time being in force in India; or stands to any such body corporate in the relation of a subsidiary company within the meaning of the Indian Companies Act, 1913, as defined by sub section (2) of section 2 of that Act), who carries on exclusively re-insurance business and is approved in this behalf by the Central Government."
} 


\subsubsection{Nationalization of General Insurance}

General insurance was finally nationalized in 1972 (effective January 1, 1973). There were 107 general insurance companies operating at the time-mainly large cityoriented companies catering to the organized sector (trade and industry). They were of different sizes, operating at different levels of sophistication. They were assigned to four different subsidiaries (roughly of equal size) of the General Insurance Corporation, which was incorporated as a holding company in November 1972 and commenced business on January 1, 1973. Its four subsidiaries were the National Insurance Company, the New India Assurance Company, the Oriental Insurance Company, and the United India Insurance Company. The head offices of the four companies are in Calcutta (now Kolkata), Bombay (now Mumbai), New Delhi, and Madras (now Chennai), respectively.

There were several goals of setting up this structure. First, the subsidiary companies were expected to "set up standards of conduct and sound practices in the general insurance business and rendering efficient customer service" (General Insurance Business (Nationalisation) Act, 1972). Second, the General Insurance Corporation was to help with "controlling their expenses." Third, it was to help with the investment of funds. Fourth, it was to bring general insurance to the rural areas of the country. Fifth, the General Insurance Corporation was also designated the National Reinsurer. By law, all domestic insurers were to cede 20 percent of the gross direct premium in India to the General Insurance Corporation under Section 101A of the Insurance Act of 1938. The idea was to retain as much risk as possible domestically. This was in turn motivated by the desire to minimize the expenditure on foreign exchange. Sixth, all four subsidiaries were supposed to compete with one another.

With 30 years of hindsight, we can examine the degree of success of each goal above. It was noted by the Malhotra Committee (1994) that the "behavior of the general insurance employees were not customer friendly" (chap. 2, sect. 2.22, p. 15). Thus, the goal of "efficient customer service" remained elusive. Cost-cutting seemed to have worked between 1973 and 1980. The cost of operation (as a percent of premium income) fell from around 30 percent in 1973 to around 24 percent in 1980 (Malhotra, 1994, Appendix 9, p. 131). Thereafter, there had not been a huge change in cost of operation. For investment funds, it was again noted that funds of the General Insurance Corporation had very low rates of return: "general insurance companies have been far too conservative in managing their equity portfolios" (Malhotra, 1994, chap. 6, sect. 6.9, p. 47). For rural expansion, the subsidiaries introduced a number of schemes such as crop insurance, cattle insurance, and the like. They also tried to stimulate rural business by raising the commissions of rural agents. Unfortunately, the companies did not make much headway in any direction for expanding rural business. With respect to reinsurance, the General Insurance Corporation did retain a large amount of reinsurance domestically in some areas of general insurance (such as motor insurance). Finally, the competition among the subsidiaries of the General Insurance Corporation remained elusive. Effectively they acted like a cartel-carving up the market into their own regional territories and acting like monopolies. 


\subsubsection{Investment Regimes: Before and After Nationalization}

The Insurance Act of 1938 required that the life insurers should hold 55 percent of their assets in government securities or other approved securities (Section 27A). In the 1940s, many insurers were part of financial conglomerates. With a 45 percent balance to play with, some insurers used these funds for their other enterprises or even for speculation. A committee headed by Cowasji Jehangir was set up in 1948 to examine these practices. The committee recommended the following amendments to the Insurance Act: Life insurers should invest 25 percent of their assets in government securities; another 25 percent should go into government securities or other approved securities; another 35 percent should go into approved investment that might include stocks and bonds of publicly traded companies (but they should be blue chip companies); and only 15 percent could be invested in other areas if the board of directors of the insurance company approved them.

In 1958, Section 27A of the Insurance Act was modified to stipulate the following investment regime:

(a) central government market securities of not less than 20 percent

(b) loans to national housing bank including (a) above should be no less than 25 percent

(c) In state government securities, including (b) above, should be no less than 50 percent

(d) In socially oriented sectors - including the public sector, the cooperative sector, housebuilding by policyholders, and own-your-own-home schemes including (c) above — should be no less than 75 percent.

How did the investment regime actually operate on the ground? The figures as presented by the Life Insurance Corporation are reproduced in Table 13.4. Broadly, loans to state and central government and their corporations and boards" has steadily fallen from 42 percent to around 18 percent in 20 years. In their place, in the category of "Central Government, State Government, and Local Government Securities," the proportion of the portfolio has gone up steadily from 57 percent in 1980 to 80 percent in 2000. In fact, the Life Insurance Corporation (along with the State Bank of India) has become one of the two largest owners of government bonds in India.

For General Insurance, Section 27B of the Insurance Act of 1938 was amended in 1976. The guideline for investment was set as follows.

(a) central government securities 25 percent

(b) state government and public sector bonds 10 percent

(c) loans to state governments and various housing schemes 35 percent.

The remaining 30 percent investment could be in the market sector in the form of equity, long-term loans, debentures, and other forms of private sector investment.

The actual level of investment by the General Insurance Corporation is shown in Table 13.5. Investment in central government securities hovered around 20 percent between 1980 and 2000. Investment in state government securities stayed much 
closer to the target of 10 percent throughout the period. Soft loans to housing rose from 8 percent in 1980 to a high of 29 percent in 1990, only to fall again to a low of 14 percent of the portfolio at the final stage. The Malhotra Committee (1994) recommended that the mandated investment of funds in government securities of the general insurance companies should be reduced to 40 percent (chap. 6, p. 50). In April 1995, the government relaxed the investment policies of the General Insurance Corporation and its subsidiaries. Therefore, in the last half of the 1990s, we see a jump in the other approved investment by the General Insurance Corporation to the 55 to 60 percent range.

Table 13.4. Investment Portfolio of the Life Insurance Corporation, 1980 to 2000 (shown as percentages)

\begin{tabular}{|c|c|c|c|c|c|c|}
\hline Year & $\begin{array}{c}\text { Loans to } \\
\text { Government }\end{array}$ & $\begin{array}{l}\text { Government } \\
\text { Bonds }\end{array}$ & $\begin{array}{c}\text { Special Central } \\
\text { Government }\end{array}$ & Unapproved & Foreign & Total \\
\hline 1980-1981 & 41.7 & 55.0 & 1.6 & 1.1 & 0.6 & 100 \\
\hline $1981-1982$ & 41.1 & 54.1 & 3.2 & 1.0 & 0.5 & 100 \\
\hline $1982-1983$ & 40.3 & 54.2 & 4.0 & 1.0 & 0.5 & 100 \\
\hline 1983-1984 & 39.1 & 54.5 & 4.9 & 1.1 & 0.5 & 100 \\
\hline 1984-1985 & 37.7 & 55.1 & 5.7 & 1.1 & 0.5 & 100 \\
\hline $1985-1986$ & 36.5 & 55.6 & 6.3 & 1.1 & 0.5 & 100 \\
\hline 1986-1987 & 35.0 & 56.8 & 6.6 & 1.0 & 0.6 & 100 \\
\hline 1987-1988 & 34.1 & 57.8 & 6.7 & 0.8 & 0.6 & 100 \\
\hline 1988-1989 & 33.2 & 58.5 & 6.7 & 1.0 & 0.6 & 100 \\
\hline 1989-1990 & 33.1 & 58.8 & 6.4 & 1.2 & 0.5 & 100 \\
\hline 1990-1991 & 33.6 & 59.2 & 5.6 & 1.1 & 0.5 & 100 \\
\hline 1991-1992 & 4.9 & 85.5 & 6.9 & 1.9 & 0.8 & 100 \\
\hline $1992-1993$ & 34.1 & 60.1 & 4.2 & 1.1 & 0.5 & 100 \\
\hline 1993-1994 & 31.4 & 63.4 & 3.6 & 1.1 & 0.5 & 100 \\
\hline 1994-1995 & 28.7 & 66.4 & 3.3 & 1.1 & 0.6 & 100 \\
\hline 1995-1996 & 26.5 & 69.0 & 2.9 & 1.2 & 0.5 & 100 \\
\hline 1996-1997 & 24.8 & 71.2 & 2.6 & 0.9 & 0.5 & 100 \\
\hline 1997-1998 & 23.1 & 73.3 & 2.4 & 0.8 & 0.4 & 100 \\
\hline 1998-1999 & 21.7 & 75.4 & 1.8 & 0.8 & 0.3 & 100 \\
\hline 1999-2000 & 19.8 & 77.9 & 1.4 & 0.6 & 0.3 & 100 \\
\hline $2000-2001$ & 18.3 & 79.8 & 1.1 & 0.5 & 0.3 & 100 \\
\hline
\end{tabular}

Source: Life Insurance Corporation annual reports, various years. 


\subsubsection{Life Insurance Business during the Nationalized Era}

Indian life insurance was nationalized in 1956. All life insurers were merged together to form one single company: the Life Insurance Corporation. By 2000, the Life Insurance Corporation had 100 divisional offices in seven zones with 2,048 branches. There were over 680,000 active agents across India with a total of 117,000 employees in the Life Insurance Corporation employed directly.

Table 13.5. Investment Portfolio of the General Insurance Corporation, 1980 to 2000 (shown as percentages)

\begin{tabular}{|c|c|c|c|c|c|c|}
\hline Year & $\begin{array}{c}\text { Central } \\
\text { Government } \\
\text { Bonds }\end{array}$ & State Bonds & Soft Loans & $\begin{array}{c}\text { Market } \\
\text { Investment }\end{array}$ & Other Loans & Total \\
\hline 1980 & 21 & 9 & 8 & 34 & 27 & 100 \\
\hline 1981 & 21 & 10 & 11 & 30 & 28 & 100 \\
\hline 1982 & 25 & 10 & 15 & 29 & 20 & 100 \\
\hline 1983 & 23 & 10 & 20 & 30 & 17 & 100 \\
\hline 1984 & 24 & 11 & 22 & 35 & 8 & 100 \\
\hline 1985 & 24 & 10 & 25 & 34 & 7 & 100 \\
\hline 1986 & 23 & 10 & 28 & 34 & 6 & 100 \\
\hline 1987 & 23 & 10 & 28 & 34 & 5 & 100 \\
\hline $1988-1989^{\mathrm{a}}$ & 21 & 11 & 29 & 33 & 7 & 100 \\
\hline 1989-1990 & 19 & 11 & 29 & 34 & 8 & 100 \\
\hline 1990-1991 & 18 & 11 & 28 & 31 & 12 & 100 \\
\hline 1991-1992 & 17 & 10 & 26 & 33 & 14 & 100 \\
\hline 1992-1993 & 17 & 10 & 26 & 36 & 11 & 100 \\
\hline 1993-1994 & 17 & 10 & 27 & 35 & 11 & 100 \\
\hline 1994-1995 & 17 & 10 & 29 & 35 & 9 & 100 \\
\hline 1995-1996 & 17 & 5 & 23 & 42 & 13 & 100 \\
\hline 1996-1997 & 18 & 6 & 20 & 42 & 15 & 100 \\
\hline 1997-1998 & 18 & 7 & 18 & 40 & 17 & 100 \\
\hline 1998-1999 & 18 & 8 & 16 & 42 & 16 & 100 \\
\hline 1999-2000 & 19 & 9 & 14 & 43 & 14 & 100 \\
\hline 2000-2001 & 21 & 11 & 14 & 44 & 10 & 100 \\
\hline
\end{tabular}

Source: General Insurance Corporation, Annual Reports, various years.

Note: Data up to 1987 are as of December 31, and for the remaining years data are as of March 31.

${ }^{\mathrm{a}}$ Denotes figures for 15 months (January 1, 1988-March 31, 1989).

There are two problems with this type of examination of the industry. First, the population of India has grown from 413 million in 1957 to over 1,000 million in 
2000. Therefore, we would expect growth in life insurance policies sold by the growth of the population alone. Second, if we measure growth in life insurance in nominal amount, for a country like India, where the annual inflation rate has averaged 7.8 percent per year between 1957 and 2002, we would expected a growth in the sale of life insurance by the sheer force of inflation. Therefore, this discussion will not indulge in such descriptions.

The largest segment of the life insurance market in India has been individual life insurance. The types of policies sold were mainly whole life, endowment, and "money back" policies. Money back policies return a fraction of the nominal value of the premium paid by the policyholder at the termination of the contract. Until recently, term life policies were not available in the Indian market. The number of new policies sold each year went from about 950,000 per year in 1957 to around 22.49 million in 2001. The total number of policies in force went from 5.42 million in 1957 to 125.79 million in 2001. Thus, on both counts there has been a 25 -fold increase in the number of policies sold. Of course, during the same period, the population has more than doubled. On a per capita basis, there were 0.0023 new policies per capita in 1957 compared with 0.0218 new policies in 2001. Total policies per capita went from 0.0131 in 1957 to 0.1218 in 2001. Thus, whether we examine the new policies sold or the total number of policies in force, there has been a 10 -fold increase during that period. Therefore, if we consider the number of individual policies to be an indication of penetration, there has been a substantial increase, part of which is directly attributable to a deliberate policy of rural expansion of the Life Insurance Corporation.

Table 13.6 provides the details of different components of life insurance business during the nationalized era. Between 1985 and 2001, total life business has grown from below 18 billion rupees to over 500 billion rupees. During that period, the price index has grown fourfold. Thus, if there had been no change in life insurance bought in real terms, it would have accounted for 78 billon rupees worth of business. Note that, even in 2001, individual life business accounts for 92 percent of the life insurance market.

In recent years, life insurance saving has played a bigger role in national saving. Figure 13.2 plots the nonlinear relationship between total national saving and life insurance premium (both as percentages of the contemporaneous GDP) for 52 years. At relatively lower levels of saving rate (that correspond to lower levels of income), a rise in saving rate does not lead to a rise in life insurance premium expressed as a fraction of GDP. In the case of India, the threshold value of saving rate seems to be around 20 percent beyond that, the life premium as a percent of GDP starts to grow rapidly. India has reached that turning point.

A similar story emerges when we examine the saving through insurers as a component of financial saving (see Table 13.7). Over a period of 10 years between 1991 and 2000, the amount of financial saving as a percent of GDP has varied from around 11 percent to 14.4 percent. Two components of this financial saving-life insurance saving and pension — saving have increased steadily over the years. 
Table 13.6. Life Insurance-Direct Premiums in Force for Domestic Risks-in India, 1985 to 2004 (in millions of U.S. dollars)

\begin{tabular}{|c|c|c|c|c|c|}
\hline Year & Total & Individual & $\begin{array}{c}\text { Individual } \\
\text { Pension }\end{array}$ & Group & $\begin{array}{c}\text { Group } \\
\text { Superannuation }\end{array}$ \\
\hline 1985 & $1,439.00$ & $1,305.60$ & 0.61 & 133.40 & 36.64 \\
\hline 1986 & $1,655.73$ & $1,497.10$ & 1.25 & 158.63 & 39.17 \\
\hline 1987 & $2,056.14$ & $1,815.95$ & 10.01 & 240.19 & 49.58 \\
\hline 1988 & $2,459.19$ & $2,212.68$ & 99.02 & 246.52 & 64.73 \\
\hline 1989 & $2,759.06$ & $2,483.13$ & 131.33 & 275.92 & 62.91 \\
\hline 1990 & $3,189.71$ & $2,878.51$ & 147.06 & 311.19 & 63.70 \\
\hline 1991 & $3,049.37$ & $2,749.45$ & 131.26 & 299.92 & 65.79 \\
\hline 1992 & $2,822.35$ & $2,564.42$ & 26.69 & 257.93 & 65.62 \\
\hline 1993 & $3,096.56$ & $2,817.43$ & 18.40 & 279.12 & 75.13 \\
\hline 1994 & $3,654.18$ & $3,324.75$ & 16.40 & 329.43 & 92.69 \\
\hline 1995 & $4,354.21$ & $3,743.76$ & 13.46 & 610.45 & 341.76 \\
\hline 1996 & $4,583.93$ & $4,124.49$ & 41.28 & 459.43 & 173.72 \\
\hline 1997 & $5,299.35$ & $4,731.80$ & 39.57 & 567.54 & 253.84 \\
\hline 1998 & $5,535.60$ & $4,946.75$ & 54.57 & 588.85 & 240.12 \\
\hline 1999 & $6,436.30$ & $5,811.79$ & 121.93 & 631.62 & 255.69 \\
\hline 2000 & $7,810.76$ & $6,529.91$ & 64.32 & 701.47 & 286.18 \\
\hline 2001 & $10,649.33$ & $9,771.61$ & 611.52 & 877.71 & 430.00 \\
\hline 2002 & $12,216.81$ & $10,268.03$ & 593.23 & 913.71 & 441.84 \\
\hline 2003 & $14,938.63$ & $12,534.63$ & 789.79 & $1,079.23$ & 534.98 \\
\hline $2004^{\mathrm{a}}$ & $17,496.40$ & $14,662.19$ & 981.96 & $1,230.37$ & 621.88 \\
\hline
\end{tabular}

Source: Swiss Reinsurance Company database.

Note: All figures were converted to U.S. dollars by using the average market exchange rate of the year.

a 2004 figures are estimates based on the actual results of the first nine months of the year.

\subsubsection{General Insurance Business during the Nationalized Era}

After the nationalization of general insurance in 1972, the government set up one holding company - the General Insurance Corporation of India. Under the holding company, there were four subsidiaries. Information about general insurance premiums earned is shown in Table 13.8. Between 1985 and 2001, the business of general insurance grew 10 -fold to 122 billion rupees. Thus, the general insurance business in India is approximately one fourth the size of the life insurance business. In 1988, fire insurance (in terms of premiums earned) accounted for about a quarter of all business. The percentage remained the same over the next 14 years. Marine insurance has shrunk in relative importance. It went from nearly 20 percent of 
general insurance to under 10 percent by 2001 . The biggest component, called "miscellaneous," has grown to occupy 68 percent of the general insurance market. This unfortunate method of categorizing lines of business can be traced back to the Insurance Act of 1938 (see Appendix 1). It placed whatever could not be classified as life insurance or fire insurance or marine insurance into a "miscellaneous"category. Thus, the biggest component of general insurance-motor insurance - is lumped with a range of other general insurance such as aviation, engineering, and crop insurance. In terms of premiums, motor insurance accounts for around 54 percent of premium income. The Tariff Advisory Committee has been unwilling to revise motor premiums upward (due to political pressure) to be consistent with higher losses experienced. As a result, the losses have mounted in motor insurance. A crude measure (of profitability) of claims as a percent of premiums earned hovered between 120 and 140 percent during 1996 and 2001 for motor insurance business. Therefore, this line of business was not profitable for these state-run enterprises. As a result, overall profitability of four subsidiaries of the General Insurance Corporation has masked the losses incurred in motor insurance.

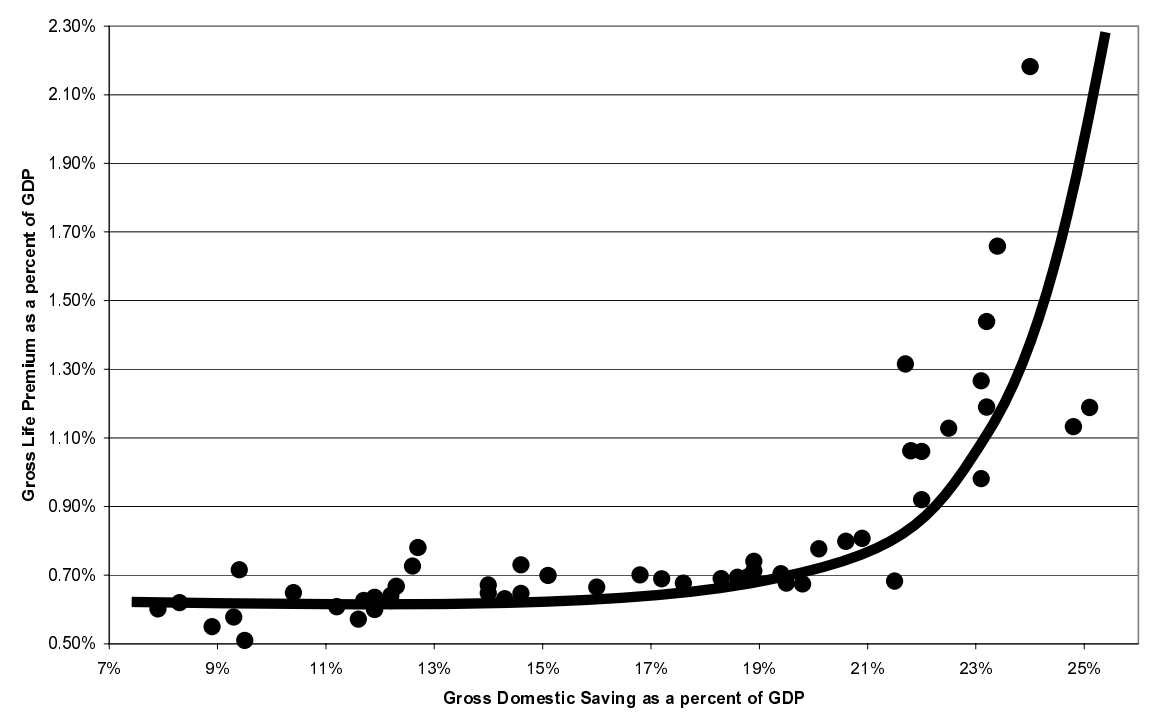

Source: Calculated based on data from the Central Statistical Organization database.

Note: The figure is plotted with gross domestic saving as a percent of gross domestic product (GDP) in the horizontal axis and gross life premium as a percent of GDP on the vertical axis. Thus, there are 52 data points, each pair representing data for a given year.

Figure 13.2. Relationship Between National Saving and Life Insurance Premiums, 1950 to 2001 
Table 13.7. Components of Financial Saving as a Percentage of Gross Domestic Product

\begin{tabular}{lrrrrr}
\hline & 1991 & 1992 & 1995 & 1999 & 2000 \\
\hline Financial Saving & 11.0 & 11.0 & 14.4 & 12.5 & 12.1 \\
Currency & 1.2 & 1.3 & 1.6 & 1.2 & 1.1 \\
Bank deposits & 3.7 & 3.2 & 6.5 & 5.2 & 4.5 \\
Stocks & 1.6 & 2.6 & 1.7 & 0.4 & 0.8 \\
Claims on government & 1.5 & 0.8 & 1.3 & 1.6 & 1.5 \\
Insurance funds & 1.0 & 1.1 & 1.1 & 1.3 & 1.5 \\
Pension funds & 2.1 & 2.0 & 2.1 & 2.6 & 2.8 \\
\hline
\end{tabular}

Source: Central Statistical Organization database.

Note: Each financial year ends March 31.

\subsubsection{How Public Insurers Reacted During the Final Countdown}

During the final years of the General Insurance Corporation as a holding company, there were a number of suggestions about what to do with the structure of the industry. The Malhotra Committee Report (1994) strongly recommended that the General Insurance Corporation cease to be the holding company and concentrate on reinsurance business only. The four subsidiaries should become independent companies. The report also noted that the subsidiaries were overstaffed (chap. 12, pp. 88-89).

But the Malhotra Report was not the final word. A study conducted by the consulting company PricewaterhouseCoopers, commissioned by the General Insurance Corporation in 2000, recommended just the opposite. It argued that, in the face of impending competition from the private companies, the subsidiaries should be merged to form a single company to better fight the competition. While these discussions were taking place, the four subsidiaries undertook restructuring. The results of this restructuring can be found by looking at the efficiency levels of the companies over the 1997 to 2003 period.

To assess the change in efficiency of these four companies, we calculated the technical efficiency of each company. The relative efficiency measure of Farrell (1957) has been formulated in a mathematical programming framework-usually called data envelopment analysis (DEA). We took the number of employees (labor), the number of offices (physical capital) and the commission paid as three inputs. We took two alternative measures of outputs: premiums and claims (see Cummins, Weiss, and $\mathrm{Zi}, 1997$, for a discussion of this issue). The results are similar for both outputs. It shows that, after some initial change, the relative efficiency level converged among the public sector general insurance companies by 2003 (see Figure 13.3). New India Insurance has consistently demonstrated the highest technical efficiency. It is well known in the literature that DEA is biased upward in small samples; thus, the absolute level of efficiency should not be taken at face value. The 
point here is that there has been a convergence among the public sector companies in terms of efficiency.

Table 13.8. General Insurance in India, 1985 to 2004 (in millions of U.S. dollars)

\begin{tabular}{|c|c|c|c|c|c|c|c|}
\hline Year & Total & Fire & Marine & $\begin{array}{l}\text { Miscella- } \\
\text { neous }\end{array}$ & $\begin{array}{l}\text { Net Claims } \\
\text { Incurred }\end{array}$ & $\begin{array}{l}\text { Profit/Loss } \\
\text { Before tax }\end{array}$ & $\begin{array}{c}\text { Assets/ } \\
\text { Liabilities, } \\
\text { Book Value }\end{array}$ \\
\hline 1979 & 508.58 & & & & & & \\
\hline 1980 & 637.52 & & & & & & \\
\hline 1981 & 718.89 & & & & & & \\
\hline 1982 & 802.74 & & & & & & \\
\hline 1983 & 886.14 & & & & & & \\
\hline 1984 & 911.01 & & & & & & \\
\hline 1985 & 976.48 & & & & & & \\
\hline 1986 & $1,129.37$ & & & & & & \\
\hline 1987 & $1,276.66$ & & & & & & \\
\hline 1988 & $1,689.86$ & 418.63 & 323.09 & 890.86 & $1,205.47$ & 243.53 & $3,394.75$ \\
\hline 1989 & $1,405.55$ & 363.23 & 258.24 & 732.63 & 927.02 & 229.12 & $3,442.44$ \\
\hline 1990 & $1,665.52$ & 390.68 & 291.25 & 930.65 & $1,085.25$ & 275.30 & $3,819.73$ \\
\hline 1991 & $1,542.67$ & 369.44 & 279.08 & 818.27 & $1,014.09$ & 294.45 & $3,637.74$ \\
\hline 1992 & $1,445.42$ & 350.85 & 273.86 & 741.76 & $1,008.24$ & 276.78 & $3,548.54$ \\
\hline 1993 & $1,523.30$ & 371.97 & 266.03 & 805.69 & 974.82 & 345.67 & $3,657.56$ \\
\hline 1994 & $1,679.26$ & 421.38 & 263.43 & 918.89 & $1,366.52$ & 160.08 & $4,425.58$ \\
\hline 1995 & $1,967.12$ & 486.61 & 296.51 & $1,105.98$ & $1,365.52$ & 256.45 & $5,089.42$ \\
\hline 1996 & $2,069.25$ & 506.70 & 278.91 & $1,214.22$ & $1,437.51$ & 307.49 & $5,282.34$ \\
\hline 1997 & $2,223.15$ & 549.13 & 290.02 & $1,384.05$ & $1,546.49$ & 446.41 & $5,931.26$ \\
\hline 1998 & $2,214.10$ & 527.76 & 247.78 & $1,438.56$ & $1,561.97$ & 354.69 & $5,937.43$ \\
\hline 1999 & $2,314.44$ & 558.75 & 237.49 & $1,518.20$ & $1,758.78$ & 267.24 & $6,473.50$ \\
\hline 2000 & $2,410.90$ & 492.19 & 227.22 & $1,691.50$ & $1,985.70$ & 163.21 & $6,894.47$ \\
\hline 2001 & $2,609.08$ & 618.66 & 225.60 & $1,764.80$ & $1,686.05$ & 95.54 & $7,182.36$ \\
\hline 2002 & $2,879.83$ & 682.87 & 249.01 & $1,947.94$ & $1,861.02$ & 105.45 & $7,927.70$ \\
\hline 2003 & $3,484.58$ & 826.26 & 301.30 & $2,356.99$ & $2,251.83$ & 127.59 & $9,592.47$ \\
\hline $2004^{\mathrm{a}}$ & $4,118.68$ & 976.62 & 356.12 & $2,785.90$ & $2,661.60$ & 150.81 & $11,338.04$ \\
\hline
\end{tabular}

Source: Swiss Reinsurance Company database.

Note: All figures were converted to U.S. dollars by using the average market exchange rate of the year.

a 2004 figures are estimates based on the actual results of the first nine months of the year.

The management of these companies negotiated a "voluntary retirement scheme" to reduce the level of staffing and implemented the plan in February 2004. Of the 80,000 employees in the four companies, the voluntary retirement scheme option was restricted exclusively to 68,000 employees. Around 12,000 development officers were kept out of the voluntary retirement scheme. A total of 8,500 employees opted for the voluntary retirement scheme from the four companies. 
Thirty-four percent of the 13,500 officers in the four companies opted for the voluntary retirement scheme; only 11 percent of the 36,000 clerical staff opted for voluntary retirement. This outcome came as a surprise to the management. They were hoping to eliminate more clerical jobs through the voluntary retirement scheme. The powerful union of clerical workers has strongly opposed a similar plan for the Life Insurance Corporation (Swain, 2004).

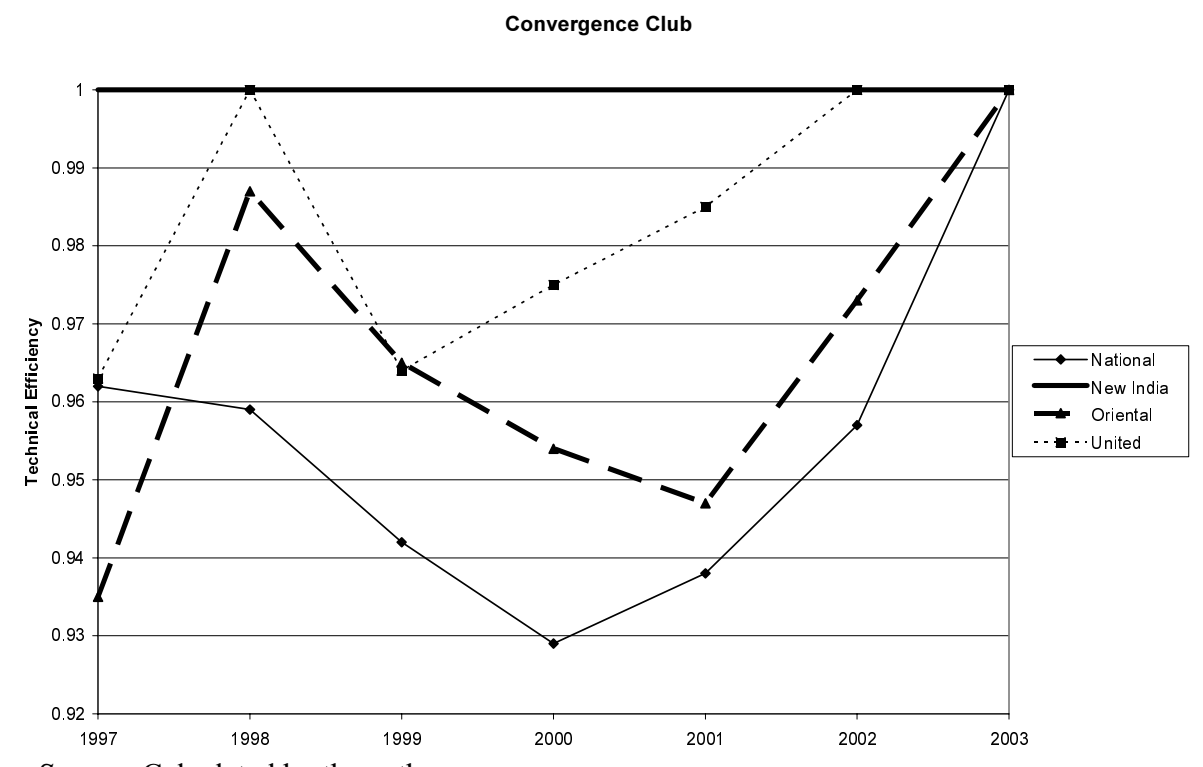

Source: Calculated by the author.

Figure 13.3. Convergence of Efficiency Among the Four Public-Sector General Insurers, 1997 to 2003

\subsubsection{Introduction of the New Legal Structure}

After the report of the Malhotra Committee was released, changes in the insurance industry appeared imminent. Unfortunately, instability of the central government in power slowed down the process. The dramatic climax came on March 16, 1999, when the Indian cabinet approved an Insurance Regulatory Authority (IRA) Bill designed to liberalize the insurance sector. The government fell in April 1999 just on the eve of the passage of the bill. Deregulation was put on hold once again.

A new government came to power with a late-1999 election, and on December 7, 1999, the new government passed the Insurance Regulatory and Development Authority Act. This Act repealed the monopoly conferred to the Life Insurance Corporation in 1956 and to the General Insurance Corporation in 1972. The authority created by the Act is now called the Insurance Regulatory and Development Authority. Under this bill, new licenses are being given to private companies. The Insurance Regulatory and Development Authority has separated out life, non-life, and reinsurance businesses. Therefore, a company must have separate licenses for 
each line of business. Each license has its own capital requirements (around U.S. \$24 million for life or non-life and $\$ 48$ million for reinsurance).

\subsubsection{Features of the Insurance Regulatory and Development Act}

The Insurance Regulatory and Development Act of 1999 set out "To provide for the establishment of an Authority to protect the interests of holders of insurance policies, to regulate, promote and ensure orderly growth of the insurance industry and for matters connected therewith or incidental thereto and further to amend the Insurance Act, 1938, the Life Insurance Corporation Act, 1956 and the General Insurance Business (Nationalisation) Act, 1972."

The Act effectively reinstituted the Insurance Act of 1938 with (marginal) modifications. Whatever was not explicitly mentioned in the 1999 Act referred back to the 1938 Act.

(1) It specified the creation and functioning of an Insurance Advisory Committee that sets rules and regulation.

(2) It stipulates the role of the "appointed actuary." He or she must be a fellow of the Actuarial Society of India. For life insurers, the appointed actuary must be an internal company employee, but he or she may be an external consultant if the company is a non-life insurance company. The appointed actuary is responsible for reporting to the Insurance Regulatory and Development Authority a detailed account of the company.

(3) Under the "Actuarial Report and Abstract," pricing of products must be given in detail, and details of the basic assumptions for valuation are required. There are prescribed forms that have to be filled out by the appointed actuary, including specific formulas for calculating solvency ratios.

(4) It stipulates the requirements for an agent-for example, insurance agents should have at least a high school diploma along with 100 hours of training from a recognized institution.

(5) The Insurance Regulatory and Development Authority has set up strict guidelines on asset and liability management of the insurance companies along with solvency margin requirements. Initial margins are set high (compared with developed countries). The margins vary with the lines of business.

Life insurers are required to observe the solvency ratio, defined as the ratio of the amount of available solvency margin to the amount of required solvency margin. The required solvency margin is based on mathematical reserves and sum at risk and the assets of the policyholders' fund. The available solvency margin is the excess of the value of assets over the value of life insurance liabilities and other liabilities of policyholders' and shareholders' funds. For general insurers, this is the higher of RSM-1 or RSM-2, where RSM-1 is based on 20 percent of the higher of (i) gross premiums multiplied by a factor A or (ii) net premiums and RSM-2 is based on 30 percent of the higher of (i) gross net incurred claims multiplied by a 
factor B or (ii) net incurred claims (factors A and B are listed in Appendix 2).

(6) It sets the reinsurance requirement for (general) insurance business. For all general insurance, a compulsory cession of 20 percent was stipulated regardless of line of business to the General Insurance Corporation, the designated national reinsurer.

(7) It sets out details of insurer registration and renewal requirements. For renewal, it stipulates a fee of one-fifth of one percent of total gross premiums written direct by an insurer in India during the preceding financial year. It seeks to give detailed background for each of the following key personnel: chief executive, chief marketing officer, appointed actuary, chief investment officer, chief of internal audit, and chief finance officer. Details of the sales force, activities in rural business, and projected values of each line of business are also required.

(8) Details of insurance advertisement in physical and electronic media must be reported to the Insurance Regulatory and Development Authority. The advertisements have to comply with the regulation prescribed in section 41 of the Insurance Act of 1938: "No person shall allow or offer to allow, either directly or indirectly, as an inducement to any person to take out or renew or continue an insurance in respect of any kind of risk relating to lives or property in India, any rebate of the whole or part of the commission payable or any rebate of the premium shown on the policy, nor shall any person taking out or renewing or continuing a policy accept any rebate, except such rebate as may be allowed in accordance with the published prospectus or tables of the insurer."

(9) All insurers are required to provide some coverage for the rural sector. ${ }^{261}$

${ }^{261}$ The formal definition of "rural sector" is "any place as per the latest census which has: (i) a population of not more than five thousand; (ii) a density of population of not more than four hundred per square kilometer; and (iii) at least seventy five percent of the male working population is engaged in agriculture. As for obligation to the rural sector, the specific minimum requirements for insurance companies are the following. In respect of a life insurer, (a) five percent in the first financial year; (b) seven percent in the second financial year; (c) ten percent in the third financial year; (d) twelve percent in the fourth financial year; (e) fifteen percent in the fifth year (of total policies written direct in that year). In respect of a general insurer, (a) two percent in the first financial year; (b) three percent in the second financial year; (c) five percent thereafter (of total gross premium income written direct in that year). In addition, each company is obligated to service the 'social sector' as follows. The 'social sector' is a sub-category of the rural sector. It consists of economically underprivileged groups within the rural areas such as the aboriginals. In respect of all insurers, (I) five thousand lives in the first financial year; (II) seven thousand five hundred lives in the second financial year; (III) ten thousand lives in the third financial year; (IV) fifteen thousand lives in the fourth financial year; (V) twenty thousand lives in the fifth year. 'Social sector' includes unorganized sector, informal sector, economically vulnerable or backward classes and other categories of persons, both in rural and urban areas." 


\subsection{Current State of Play and Future Prospects}

Starting in early 2000, the Insurance Regulatory and Development Authority started granting charters to private life and general insurance companies. Appendix 3 lists all companies with charters as of December 31, 2003.

By the end of 2003, 13 life insurers had charters to operate-1 public (the old monopoly) and 12 private companies. All of the private companies have foreign partners in life business. Almost all the general insurers also have foreign partners. One such charter was very special. The State Bank of India (SBI) announced a joint venture partnership with Cardif SA of France (the insurance arm of BNP Paribas Bank). Since the SBI is a bank, the Reserve Bank of India (RBI) needed to clear the participation of the SBI because banks are allowed to enter other businesses on a case-by-case basis. Thus, the SBI became the test case.

The latest group to receive an outright charter for operating a life insurance company is the Sahara Group (on March 5, 2004). Sahara's entry is notable for two reasons. First, Sahara would be the only company to enter the Indian life insurance market without a foreign partner, thus becoming the only purely domestic company to be granted a license to operate in the insurance sector. Second, it operates the largest non-bank financial company in India, the first to operate in the life insurance sector.

Thirteen general insurance companies were operating in India at the end of 2003. Four are public sector companies - the erstwhile subsidiaries of the General Insurance Corporation that operated as nationalized companies - and the rest are private sector companies.

In India, life insurance business in 2002 amounted to U.S. $\$ 12.2$ billion, and non-life insurance business amounted to $\$ 3.3$ billion. Thus, the life business is almost four times as large as the non-life business. The rate of annual growth in the year 2001-2002 was 43 percednt in life insurance and 13.6 percent in non-life insurance. The total premiums underwritten by the Life Insurance Corporation of India was around \$11 billion in fiscal year 2001-2002. Income of the Life Insurance Corporation during the same period was $\$ 16$ billion. Twelve companies in the private sector had foreign company participation up to the permissible limit of 26 percent of equity share capital. Over a period of 10 years (1991 to 2001), the Life Insurance Corporation has averaged a real growth rate of 12 percent.

During the same 2001-2002 period, the gross direct premium income of the four public sector companies, the subsidiaries of the General Insurance Corporation of India, was U.S. \$2.9 billion. The real growth rate over a period of 10 years (1991 to 2001) has been 5 percent annually. The general insurance business includes motor vehicle insurance, marine insurance, fire insurance, personal accident insurance, health insurance, aviation insurance, rural insurance, and others. At present, the General Insurance Corporation is the only reinsurer. Foreign capital of around \$140 million has been so far invested in the new life insurance companies in India. 


\subsubsection{Distribution Channels}

The Life Insurance Corporation has traditionally sold life insurance using tied agents (in-house sales forces are not a traditional feature of the Indian life insurance market). All life insurers have tied agents working on a commission basis only, and the majority of private-sector insurers have followed this approach in distributing life insurance products. Nevertheless, because banks are now able to sell insurance products, bancassurance has made a major impact in life insurance sales. Almost all private-sector insurers have formed alliances with banks, with a few of the insurers using bancassurance as their major source of new business. For example, in 2003, SBI Life and Aviva Life sold more than half of their policies through banks. In 2004, private insurers sold more than 30 percent of their policies through the banking channel. In India, banks are used only as a channel of distribution because current law prohibits bank employees from accepting commission for selling insurance policies.

\subsubsection{Reinsurance}

In the reinsurance business, the Insurance Regulatory and Development Authority (General Insurance-Reinsurance) Regulations, 2000, stipulated the following:

The Reinsurance Program shall continue to be guided by the following objectives to: (a) maximize retention within the country; (b) develop adequate capacity; (c) secure the best possible protection for the reinsurance costs incurred; (d) simplify the administration of business.

For life reinsurance, the government has allowed private reinsurance companies to operate in exactly the same way it has allowed private life insurance companies. A foreign reinsurer is allowed to have up to 26 percent share in a life reinsurance company. However, until the end of 2003, there has been no taker of this offer. The reason that no private reinsurance company has stepped forward is easy to see. For most reinsurers, the main business is (still) general reinsurance. In OECD (Organisation for Economic Co-operation and Development)-member countries, around 95 percent of life insurance risk is retained domestically. For general insurance, however, the average risk retained is around 85 percent (OECD, 2003).

\subsubsection{Market Share}

We can get an indication of where the life insurance market is heading by examining the new business written during eleven months of the fiscal year of 2003 (April 2003 to February 2004). The distribution of premiums is shown in Table 13.9. The Life Insurance Corporation has slightly over 87 percent of the market share, leaving the rest for the twelve private companies. Among the private companies, ICICIPrudential has the largest market share at 4.43 percent, followed by Birla Sun Life at 1.90 percent. Tata AIG and HDFC Standard Chartered are the only two other companies with more than 1 percent market share. 
Table 13.9. Market Share for Premiums in the Indian Life Insurance Market (March 2003 to February 2004)

\begin{tabular}{lc}
\hline \multicolumn{1}{c}{ Company } & Market Share (\%) \\
\hline Public Sector & 87.22 \\
Life Insurance Corporation of India & 87.22 \\
Private Sector & 12.78 \\
Allianz Bajaj Life Insurance Company Limited & 0.87 \\
ING Vyasa Life Insurance Company Limited & 0.35 \\
AMP Sanmar Assurance Company Limited & 0.16 \\
SBI Life Insurance Company Limited & 0.89 \\
TATA AIG Life Insurance Company Limited & 1.10 \\
HDFC Standard Life Insurance Co. Limited & 1.15 \\
ICICI Prudential Life Insurance Co. Limited & 4.43 \\
Aviva & 0.46 \\
Birla Sun-Life Insurance Company Limited & 1.90 \\
OM Kotak Mahindra Life Insurance Co. Ltd. & 0.53 \\
Max New York Life Insurance Co. Limited & 0.81 \\
MetLife Insurance Company Limited & 0.14 \\
\hline
\end{tabular}

Source: IRDA Journal, April 2004, pp. 38-39.

The market share for general insurance companies is shown in Table 13.10. Public-sector companies have close to 86 percent of the premiums, and the rest are with private-sector companies. Once again, ICICI-Lombard has the largest market share among the private companies. Bajaj-Allianz comes next with 2.95 percent of the market share. Tata-AIG has a market share of 2.25 percent, and IFFCO-Tokio has 1.97 percent.

\subsubsection{Investment Regimes}

Investment regimes in insurance in India have always had quantitative restrictions. Current legal requirements are explained in Table 13.11 for the life insurance business and in Table 13.12 for general insurance. At least half of the investment has to be either directly in government securities (bonds) or for infrastructure investments (which also take the form of government bonds). These investment options are "safe" because they are fully backed by the government. Of course, this also means that they earn the lowest rate of return in the Indian market. The government (both at the federal and state levels) has used insurance business as a way of raising capital. Unfortunately, much of it has been spent on consumption expenditure leading to substantial increase in government debt. 
Table 13.10. Gross Premiums Underwritten by General Insurers (April 2003 to February 2004)

\begin{tabular}{lc}
\hline \multicolumn{1}{c}{ Company } & Market Share (\%) \\
\hline Public Sector & $\mathbf{8 5 . 7 9}$ \\
National Insurance Company Limited & 21.39 \\
New India Assurance Company Limited & 24.22 \\
Oriental Insurance Company Limited & 18.13 \\
United India Insurance Company Limited & 19.38 \\
Private Sector & $\mathbf{1 4 . 2 1}$ \\
Bajaj Allianz General Insurance Co. Limited & 2.95 \\
ICICI Lombard General Insurance Co. Ltd. & 3.16 \\
IFFCO-Tokio General Insurance Co. Ltd. & 1.97 \\
Reliance General Insurance Co. Limited & 1.07 \\
Royal Sundaram Alliance Insurance Co. Ltd. & 1.58 \\
TATA AIG General Insurance Co. Limited & 2.25 \\
Cholamandalam General Insurance Co. Ltd. & 0.57 \\
Export Credit Guarantee Corporation & 2.66 \\
HDFC Chubb General Insurance Co. Ltd. & 0.66 \\
\hline
\end{tabular}

Source: IRDA Journal, April 2004, p. 40.

Table 13.11. Investment Regulation of Life Insurance Business

\begin{tabular}{|c|c|c|}
\hline & Type of Investment & Percentage \\
\hline I & Government securities & $25 \%$ \\
\hline II & Government securities or other approved securities (including (I) above) & Not less than $50 \%$ \\
\hline \multirow[t]{4}{*}{ III } & Approved investments as specified in Schedule I & Not less than $15 \%$ \\
\hline & Infrastructure and social sector & \\
\hline & $\begin{array}{l}\text { Explanation: For the purpose of this requirement, infrastructure and social } \\
\text { sector shall have the meaning as given in regulation 2(h) of Insurance } \\
\text { Regulatory and Development Authority (Registration of Indian Insurance } \\
\text { Companies) Regulations, 2000, and as defined in the Insurance Regulatory } \\
\text { and Development Authority (Obligations of Insurers to Rural and Social } \\
\text { Sector) Regulations, 2000, respectively. }\end{array}$ & \\
\hline & Others to be governed by exposure/prudential norms specified in Regulation 5 & $\begin{array}{l}\text { Not exceeding } \\
20 \%\end{array}$ \\
\hline IV & $\begin{array}{l}\text { Other than in approved investments to be governed by exposure/prudential } \\
\text { norms specified in Regulation } 5\end{array}$ & $\begin{array}{l}\text { Not exceeding } \\
15 \%\end{array}$ \\
\hline
\end{tabular}

Source: Gazette of India Extraordinary Part III Section 4. Insurance Regulatory and Development Authority (Investment) Regulations, 2000. 
Table 13.12. Investment Regulation of General Insurance Business

\begin{tabular}{|c|c|c|}
\hline & Type of Investment & Percentage \\
\hline I & Central government securities & Not less than $20 \%$ \\
\hline II & $\begin{array}{l}\text { State government securities and other guaranteed securities, including (i) } \\
\text { above }\end{array}$ & Not less than $30 \%$ \\
\hline III & $\begin{array}{l}\text { Housing and loans to state government for housing and fire-fighting } \\
\text { equipment }\end{array}$ & Not less than $5 \%$ \\
\hline IV & Investments in approved investments as specified in Schedule II & \\
\hline \multirow[t]{2}{*}{ (a) } & Infrastructure and Social Sector & Not less than $10 \%$ \\
\hline & $\begin{array}{l}\text { Explanation: For the purpose of this requirement, infrastructure and social } \\
\text { sector shall have the meaning as given in regulation 2(h) of Insurance } \\
\text { Regulatory and Development Authority (Registration of Indian Insurance } \\
\text { Companies) Regulations, 2000, and as defined in the Insurance Regulatory } \\
\text { and Development Authority (Obligations of Insurers to Rural and Social } \\
\text { Sector) Regulations, 2000, respectively. }\end{array}$ & \\
\hline (b) & $\begin{array}{l}\text { Others to be governed by exposure/prudential norms specified in Regulation } \\
5\end{array}$ & $\begin{array}{l}\text { Not exceeding } \\
\quad 30 \%\end{array}$ \\
\hline $\mathrm{V}$ & $\begin{array}{l}\text { Other than in approved investments to be governed by exposure/prudential } \\
\text { norms specified in Regulation } 5\end{array}$ & $\begin{array}{l}\text { Not exceeding } \\
25 \%\end{array}$ \\
\hline
\end{tabular}

Source: Gazette of India Extraordinary Part III Section 4. Insurance Regulatory and Development Authority (Investment) Regulations, 2000.

Recent figures for investment regimes across different companies in the life insurance sector and in the general insurance sector reveal some differences (Rao, 2003).

The Life Insurance Corporation has 64 percent invested in government securities and other approved securities. For the private sector as a whole, the corresponding figure is 60 percent, ranging from 54 percent (ICICI Prudential) to 70 percent (AMP Sanmar). Infrastructure investment for the Life Insurance Corporation was 14 percent and 16 percent for the private companies as a group, ranging from a high of 20 percent for AMP Sanmar and Allianz Bajaj to a low of 0 percent for Aviva. Since Aviva started its operation relatively recently, the figure is somewhat unusual. In the "other approved" investment category, the Life Insurance Corporation has invested 22 percent. The average for the private sector in this category is 19 percent. In the unapproved category, the Life Insurance Corporation has no investment at all, whereas in the private sector 5 percent of the total is in this category. OM Kotak leads this category with 13 percent. Most of the other companies have no investment in this area.

In the general insurance sector, public-sector companies invested 35 percent in government securities, whereas the private sector has 41 percent in that category. For the public-sector companies, it ranges from a low of 29 percent by the Oriental Insurance Company to a high of 42 percent by the National Insurance Company. For the private sector, it varies between 35 percent by Tata AIG and 50 percent by IFFCO Tokio. The other big category is a catchall of "other investments." In that category, the public sector has 49 percent, whereas the private sector only has 39 percent. 


\subsubsection{Insurance in the Rural Sector in $\mathbf{2 0 0 3}$}

Insurers have rural sector and social sector obligations (see footnote 6). The requirements are different for life and general business and also differ depending on the number of years in business. Data for private life insurers show that, on average, 13 percent of private life insurance policies have been sold in the rural sector. Among the life insurers, there is great variation. The new entrant-Aviva-virtually did not sell any, whereas ING Vyasa sold almost 35 percent of its policies in the rural areas during the fiscal year 2002-2003. Surprisingly, very few of the agents of ING Vyasa are rural. Similarly, MetLife sold $26 \%$ of its policies in the rural areas. Very few of its agents are rural (IRDA, 2002-2003). These companies sold a few large group policies to agribusiness and, thus, they qualified for being "rural" because the locations of these large businesses are in rural areas. For private general insurers, 3.9 percent of all policies sold were rural. The highest proportions are for Bajaj-Allianz and IFFCO-Tokio with 5.87 percent and 5.42 percent, respectively. These figures are surprising, because these companies have very few rural agents. The average for public insurance companies is 6.4 percent (figures are for April 2002 to March 2003).

\subsubsection{Price Dispersion of Life Insurance Products}

Life insurance products such as whole life or endowment or money back policies have two components: saving and security. Specifically, there is an element that pays even when a policyholder survives the duration the policy is in force. Therefore, the "price" or the premium obscures the protection element offered by such policies. Hence, it is somewhat difficult to compare such products. Many insurance products have additional benefits (called riders). For example, buying bags of fertilizer in villages might include one-year term life benefits. Thus, if a product also has riders, it becomes even more difficult to value it because of the embedded options.

The simplest product to compare across sellers is term life, because it only has one element. It pays the beneficiary in case the buyer dies within a specific time period. When the Life Insurance Corporation was a monopoly, there was nothing else to compare with its term life policy. Now, the buyer has an array of options. How do they compare? This question has been investigated by Rajagopalan (2004), and the results are reported in Table 13.13. The table compares policies of 5, 10, 15, 20 , and 25 years for a 30 -year-old ordinary man for the Life Insurance Corporation, HDFC, ICICI Prudential, Tata-AIG, Allianz Bajaj, Birla Sunlife, and Max New York with a sum assured of 100,000 rupees. The first striking observation is that ratio of the maximum and the minimum premiums is 2.16 for a 5 -year term and 2.60 for a 30 -year term. Therefore, the dispersion in price is strikingly high for very similar products. The degree of price dispersion might be expected to decline as the market matures. The second striking feature is that it is not the same company that quotes a consistently low price, but the same company (Tata-AIG) quotes the consistently highest price. There is a problem with comparability here, because Tata-AIG quotes are for a 35-year-old rather than a 30-year-old. The results are quite similar for a sum assured of 500,000 rupees. 
: Table 13.13. Comparison of Premiums as of October 31, 2002, for Pure Term Insurance for Ordinary Males

\begin{tabular}{|c|c|c|c|c|c|c|c|c|c|}
\hline & \multicolumn{7}{|c|}{ Insurer } & & \\
\hline & LIC & HDFC & ICICI Prudential ${ }^{\mathrm{a}}$ & Tata-AIG $^{\mathrm{b}}$ & Allianz Bajaj & Birla Sunlife & Max New York & & \\
\hline Age & 30 & 30 & 30 & 35 & 30 & 30 & 30 & & \\
\hline $\begin{array}{l}\text { Sum Assured } \\
\text { (in rupees) }\end{array}$ & 500,000 & 500,000 & $1,000,000$ & 500,000 & 500,000 & 500,000 & 500,000 & & \\
\hline Term (years) & & & \multicolumn{5}{|c|}{ Yearly Premium (in rupees) } & & \\
\hline 5 & n.a. & & 2,455 & 2,575 & 1,655 & 1,875 & 1,190 & & \\
\hline 10 & 1,140 & & 2,504 & 2,585 & 1,805 & 1,875 & 1,225 & & \\
\hline 15 & 1,285 & 1,510 & 2,553 & 3,010 & 2,050 & 1,875 & 1,265 & & \\
\hline 20 & 1,528 & 1,535 & 2,680 & 3,450 & 2,440 & 1,905 & 1,375 & & \\
\hline 25 & n.a. & & & 4,160 & & 1,980 & 1,600 & & \\
\hline 30 & n.a. & 1,790 & & & & & & & \\
\hline $\begin{array}{l}\text { Sum Assured } \\
\text { (in rupees) }\end{array}$ & 100,000 & 100,000 & 100,000 & 100,000 & 100,000 & 100,000 & 100,000 & & \\
\hline Term (yrs) & \multicolumn{7}{|c|}{ Yearly Premium (in rupees/100,000 sum assured) } & Best Deal & Max/Min (Ratio) \\
\hline 5 & & & 245.5 & 515 & 331 & 375 & 238 & 238 & 2.16 \\
\hline 10 & 228 & & 250.4 & 517 & 361 & 375 & 245 & 228 & 2.27 \\
\hline 15 & 257 & 302 & 255.3 & 602 & 410 & 375 & 253 & 253 & 2.38 \\
\hline 20 & 305.6 & 307 & 268 & 690 & 488 & 381 & 275 & 268 & 2.57 \\
\hline 25 & & & & 832 & & 396 & 320 & 320 & 2.60 \\
\hline 30 & & 358 & & & & & & 358 & \\
\hline
\end{tabular}

Source: R. Rajagopalan (2004).

Note: For the year 2002 (the year for which the data was taken), the average value of one U.S. dollar was approximately 49 rupees. SBI Life and ING

Vysya do not offer a pure level term plan. Data are not available on the web sites of Om Kotak Mahindra and ANP Sanmar.

${ }^{a}$ The premiums per 100,000 rupees assured is likely to be higher for ICICI Prudential because they are based on the quotes for a sum assured of one million rupees.

${ }^{b}$ TATA-AIG quotes are for 35-year-old male. Its quotes for a 30-year-old male will be lower. 


\subsubsection{Future Prospects: Market Size}

At the end of 2002, the size of the Indian insurance market (in terms of premium volume) was slightly bigger than that of Sweden and 20 percent smaller than that of Ireland (Sigma, 2003). So why would foreign insurance companies be interested in the Indian market? The answer, of course, is that the growth potential of the Indian market is much higher over the coming decades.

Although many commentators have written about India's growth potential, actual estimates of where the Indian GDP will be over the next decades have come only very recently. One is by Wilson and Purushothaman (2003) and the other is by Rodrik and Subramanian (2004). There are two critical ingredients in our approach. First, we need to understand the factors contributing to economic growth in India. Second, we need to understand how the economic growth will influence the saving rate in general and saving in the form of insurance in particular.

\section{Growth Accounting}

Wilson and Purushothaman (2003) posit a long-term economic growth rate of 6 percent per annum. However, their model is virtually driven by demographics. Rodrik and Subramanian (2004), on the other hand, show that India has had sustained growth in labor productivity, with a very low variation. In addition, the proportion of people who are economically dependent on others in the labor force (called the dependency ratio) will decline from 0.68 in 2000 to 0.48 in 2025. This alone will increase the saving rate from current 25 percent of GDP to 39 percent of GDP. Just these factors of productivity growth and favorable demographics alone will produce an aggregate growth rate of around 7 percent per year. There is also evidence that the total factor productivity in India is below 60 to 70 percent below where it should be. Institutional reforms (a stable democratic polity, reasonable rule of law, and protection of property rights) needed for the so-called second round of economic growth are already in place. Institutional quality not only helps economic growth, it also makes economic systems reasonably resistant to economic shocks. Moreover, improvement in labor quality due to higher levels of educational attainment will also contribute to economic growth. Conservatively, these factors will contribute 1 percent of additional growth rate to the GDP. Overall, therefore, a conservative estimate shows that the GDP growth rate can be 8 percent per year on a sustained basis.

\section{Insurance Sector and Economic Growth}

It is well known that growth in income is positively related to demand for insurance. What is the exact relationship? This question has to be answered empirically for each country. For India, there is a clear nonlinear relationship between total saving and life insurance saving. It can be shown that the relationship is contemporaneous. In other words, there seems to be very few backward and forward linkages: past overall saving does not seem to influence future saving in the form of life insurance and vice versa.

From this, we can project forward the demand for life insurance in real terms using the economic growth estimate described above. This method gives us an 
estimate of U.S. $\$ 140$ billion in today's dollars for life insurance in India in 2020. A similar technique also gives us an estimate of general insurance demand in 2020 of $\$ 60$ billion in today's dollars. Assuming a retention rate of 95 percent in the life insurance market and a retention rate of 85 percent in the general insurance market (OECD, 2003), we arrive at a reinsurance market of $\$ 16$ billion in today's dollars for 2020 .

These projections completely ignore two important elements of the insurance sector: pension and health care. Again, if we add conservative values (of 3 percent of GDP each) in each of these markets, another $\$ 240$ billion will be added to the above estimates. Excluding pension and health, we have a conservative projection of $\$ 180$ billion in 2020. If we include health and pension, the estimate will balloon to $\$ 440$ billion, thus making it as large as the Japanese market in 2002.

\subsubsection{Future Prospects: Market Share}

How will the life insurance market be divided between the incumbent Life Insurance Corporation and the newcomers in coming years? Models of market share have shown that, in a fast-growing market, the first few years are critical (see Guerrero and Sinha, 2004). There are three important elements to consider when formulating a picture of the future life insurance market in India: (1) The Life Insurance Corporation has a vast distribution network in the rural and semi-urban areas that would be hard to duplicate. One potential way to duplicate this reach would be to sell insurance through banks, and some insurers have already embarked on this road. (2) Since the Life Insurance Corporation started with 100 percent of the market share, it will lose market share simply because of expansion of the market itself and less because of losing existing customers. The Life Insurance Corporation is the only financial institution in the top 50 trusted brand names in India by a survey of the Economic Times newspaper (http://economictimes.indiatimes.com/articleshow/ 362862.cms). (3) As life insurance benefits accrue over time, it becomes more expensive to switch-because switching means a loss of accrued benefits. With the rapid expansion of life insurance, the market share of the Life Insurance Corporation could fall below the 50 percent mark within five years.

For the general insurance business, private companies will have easier access to the market. Unlike life insurance, it is not expensive to switch insurers because most policies are of one year or less. The problem of tariffication makes competitive pricing difficult for the newcomers. In addition, reliable data on hazard rates are not available for many risks.

\subsection{CONCLUSIONS}

India is among the important emerging insurance markets in the world. Life insurance will grow very rapidly over the next decades in India. The major drivers of this growth include sound economic fundamentals, a rising middle class, an improving regulatory framework, and rising risk awareness. The fundamental regulatory changes that occurred in the insurance sector in 1999 will be critical for future growth. Despite the restriction of 26 percent on foreign ownership, large 
foreign insurers have entered the Indian market. State-owned insurers still have dominant market positions, but this will probably change over the next decade. In the life sector, new private insurers are bringing new products to the market, and they are using innovative distribution channels to reach a broader range of the population. There is huge market potential in the largely undeveloped private pension market and in the health insurance business. The Indian general insurance segment is still heavily regulated. Three quarters of premiums are generated under the tariff system. Reinsurance in India is mainly provided by the General Insurance Corporation of India, which receives 20 percent compulsory cessions from other general insurers. Finally, the rural sector has potential for both life and general insurance. To realize this potential, designing suitable products is important. Insurers will need to pay special attention to the characteristics of the rural labor force, such as the prevalence of irregular income streams and the preference for simple products.

\subsection{APPENDIX 1: Definitions of Various Lines of Business in the Insurance Act of 1938}

Section 2(11), Insurance Act, 1938: "Life Insurance Business" means the business of effecting contracts of insurance upon human life, including any contract whereby the payment of money is assured on death (except death by accident only) and the happening of any contingency dependent on human life, and any contract which is subject to payment of premiums for a term dependent on human life and shall be deemed to include

(a) the granting of disability and double or triple indemnity accident benefits, if so provided in the contract of insurance;

(b) the granting of annuities upon human life; and

(c) the granting of superannuation allowances and annuities payable out of any fund applicable solely to the relief and maintenance of persons engaged or who have been engaged in any particular profession, trade or employment or of the dependents of such persons.

Section 2(6-A), Insurance Act, 1938: "Fire Insurance Business" means the business of effecting, otherwise than incidentally to some other class of insurance business, contracts of insurance against loss by or incidental to fire or other occurrence customarily included among the risks insured in fire insurance policies.

Section 2(13-A), Insurance Act, 1938: "Marine Insurance Business" means the business of effecting contracts of insurance upon vessels of any description, including cargoes, freights and other interests which may be legally insured, in or in relation to such vessels, cargoes and freights, goods, wares, merchandise and property of whatever description insured for any transit by land or water, or both, and whether or not including warehouse risks or similar risks in addition or as incidental to such transit, and includes any other risks customarily included among the risks insured against in marine insurance policies. 
Section 2(13-B), Insurance Act, 1938: "Miscellaneous Insurance Business" means the business of effecting contracts of insurance which is not principally or wholly of any kind or kinds included in Section 2 (6-A), 2 (11) and 2 (13-A) of the Insurance Act, 1938.

\subsection{APPENDIX 2: Detailed Factors for Each Major Line of Insurance Business}

\begin{tabular}{lll}
\hline Line of Business & Factor A & Factor B \\
\hline Fire & 0.5 & 0.5 \\
Marine: marine cargo & 0.7 & 0.7 \\
Marine: marine hull & 0.5 & 0.5 \\
Miscellaneous & & \\
Motor & 0.85 & 0.85 \\
Engineering & 0.5 & 0.5 \\
Aviation & 0.9 & 0.9 \\
Liability & 0.85 & 0.85 \\
Rural insurance & 0.5 & 0.5 \\
Other & 0.7 & 0.07 \\
Health & 0.85 & 0.85 \\
\hline
\end{tabular}




\subsection{APPENDIX 3: Insurance/Reinsurance Companies in India (December} 31, 2003)

\begin{tabular}{|c|c|}
\hline Life Insurers & General Insurers \\
\hline Public Sector & Public Sector \\
\hline Life Insurance Corporation of India & National Insurance Company Limited \\
\hline Private Sector & New India Assurance Company Limited \\
\hline Allianz Bajaj Life Insurance Company Limited & Oriental Insurance Company Limited \\
\hline Birla Sun-Life Insurance Company Limited & United India Insurance Company Limited \\
\hline HDFC Standard Life Insurance Co. Limited & Private Sector \\
\hline ICICI Prudential Life Insurance Co. Limited & Bajaj Allianz General Insurance Co. Limited \\
\hline ING Vysya Life Insurance Company Limited & ICICI Lombard General Insurance Co. Ltd. \\
\hline Max New York Life Insurance Co. Limited & IFFCO-Tokio General Insurance Co. Ltd. \\
\hline MetLife Insurance Company Limited & Reliance General Insurance Co. Limited \\
\hline Om Kotak Mahindra Life Insurance Co. Ltd. & Royal Sundaram Alliance Insurance Co. Ltd. \\
\hline SBI Life Insurance Company Limited & TATA AIG General Insurance Co. Limited \\
\hline TATA AIG Life Insurance Company Limited & Cholamandalam General Insurance Co. Ltd. \\
\hline AMP Sanmar Assurance Company Limited & Export Credit Guarantee Corporation \\
\hline Dabur CGU Life Insurance Co. Pvt. Limited & HDFC Chubb General Insurance Co. Ltd. \\
\hline \multicolumn{2}{|c|}{ Reinsurer } \\
\hline \multicolumn{2}{|c|}{ General Insurance Corporation of India } \\
\hline
\end{tabular}

\subsection{REFERENCES}

Annual Report of the Ministry of Finance (Section 3, Insurance Division, http://finmin.nic.in/the_ministry/dept_eco_affairs/budget/annual_report/9596ea3.pdf).

Bhattacharya, Saugata and Urjit R. Patel (2003). "Reform strategies in the Indian financial sector," paper presented to the Conference on India's and China's Experience with Reform and Growth, November.

Central Statistical Organization database.

Cummins, David, Mary Weiss, and Hongmin Zi (1997). "Organizational form and efficiency," Financial Institutions Center, Working Paper No. 97-2, Wharton School, University of Pennsylvania.

Farrell, M. (1957). "The measurement of productive efficiency," Journal of the Royal Statistical Society, Series A, 120, 253-281.

Gazette of India Extraordinary Part III Section 4 (2000). Insurance Regulatory and Development Authority (Investment) Regulations. 
General Insurance Corporation (various years). Annual reports.

Guerrero, Victor and Tapen Sinha (2004). "Statistical analysis of market penetration in a mandatory privatized pension market using generalized logistic curves," Journal of Data Science, 2, 196-211.

Indian Insurance Commissioner's Report (1929). Her Majesty's Stationery Office, London.

Insurance Regulatory and Development Authority Annual Report (IRDA) (2002-2003). Appendix III.

IRDA Journal (2004). "Market share for premiums: Life market (March 2003-February 2004)," April, 38-39.

IRDA Journal (2004). "Gross premium underwritten by general insurance companies (April 2003-February 2004),” April, 40.

Life Insurance Corporation (various years). Annual reports.

Malaviya, H. D. (n.d.). "Insurance in India."

Malhotra Committee Report on Reforms in the Insurance Sector (1994). Government of India, Ministry of Finance, New Delhi.

Office of Economic and Cultural Development (2003). OECD Handbook on Insurance, Paris.

Press Trust of India (2004). "India leads the world in road accident deaths," wire report, January 3.

Rajagopalan, R. (2004). "Valuing the term insurance products in the Indian market," paper presented to the Fifth Global Conference of the Actuaries, January 25, New Delhi.

Rao, G. V. (2003). "Playing it safe," IRDA Journal, November, 14-16.

Rodrik, Dani and Arvind Subramanian (2004). "Why India can grow at seven percent," Economic and Political Weekly, April 17.

Sigma (2003). “World insurance in 2002.” Swiss Re.

Srinivasan, K. K. (2003). "Transition from tariff model of pricing non-life insurance in emerging markets: Issues \& prospects," paper presented to the Seventh Conference of the Asia Pacific Risk an Insurance Association Conference, Bangkok, July 23.

Swain, Shitanshu (2004). "LIC refusing to see the writing on the wall," Financial Express, April 19.

Swiss Reinsurance Company database.

Tripathi, Dwijendra (2004). The Oxford History of Indian Business (Oxford University Press, Oxford).

Vaidyanathan, L. S. (1934). "Mortality experience of assured lives in India, 1905-1925," Journal of the Institute of Actuaries, 60, 5-66.

Vaidyanathan, L. S. (1939). "Mortality experience of assured lives in India, 1925-1935," Journal of the Institute of Actuaries, 70, 42-71.

Wilson, Dominic and Rupa Purushothaman (2003). "Dreaming with BRICs: The Path to 2050," Goldman and Sachs, Global Economics Paper No. 99, October. 


\subsection{LEXICON}

Bancassurance. The integration of banking with insurance. In India, so far, it has mostly meant selling insurance products in banks. Given that bank employees are not allowed to accept commissions for selling insurance directly, banks have created other indirect incentive schemes.

General insurance. In India this refers to property-casualty insurance. This term is used in most Commonwealth countries.

General Insurance Corporation (GIC). The company formed after the nationalization of property-casualty insurance business in India in 1972. It formed a monopoly. GIC also became the national reinsurer.

Insurance Act of 1938. The fundamental legal basis for the Indian insurance industry. The Insurance Regulatory and Development Act of 1999 was superimposed on the Insurance Act of 1938 .

Insurance Regulatory and Development Act of 1999. This law deregulated insurance business in India. It allowed for private national company participation and limited foreign participation in the Indian insurance market. It created the Insurance Regulatory and Development Authority as the regulatory body of insurance business.

Life Insurance Corporation (LIC). The company formed after the nationalization of the life insurance business in India in 1956. It formed a monopoly.

Malhotra Committee Report of 1994. The basis of recent regulatory changes under the Insurance Regulatory and Development Act of 1999.

Nationalization. In India nationalization of the insurance industry took place in two stages. Life insurance was nationalized in 1956. Property-casualty insurance was nationalized in 1972.

Rural insurance. In India all insurers must have certain proportion of their business conducted in rural India.

Tariff Advisory Committee. The price-setter for property-casualty business in India. The committee is supposed to be phased out in the near future.

Tied agents. Insurance agents who work on a commission basis only. Most life insurance companies in India used tied agents to distribute life insurance products. 